\title{
Electrochemical measurements and thermodynamic calculations of redox equilibria in pallasite meteorites: Implications for the eucrite parent body
}

\author{
Kevin Righter, ${ }^{1, *}$ Richard J. ARCulus, ${ }^{1, \dagger}{ }^{\dagger}$ John W. Delano, ${ }^{2}$ and CaSsi Paslick ${ }^{1}$ \\ 'Department of Geological Sciences, University of Michigan, Ann Arbor, MI 48109, USA \\ ${ }^{2}$ Department of Geological Sciences, State University of New York, Albany, NY 12222, USA
}

(Received September 11, 1989; accepted in revised form April 2, 1990)

\begin{abstract}
The intrinsic oxygen fugacity (IOF) of olivine separates from the Salta, Springwater, and Eagle Station pallasites was measured between 850 and $1150^{\circ} \mathrm{C}$ using oxygen-specific solid zirconia electrolytes at $10^{5} \mathrm{~Pa}$. The experimental apparatus consisted of a double-opposed clcctrolyte configuration with a $\mathrm{CO}-\mathrm{CO}_{2}$ gas-mix bridging atmosphere. Four initial IOF measurements on Salta olivines revealed the effects of grain size and cell memory on experimental results; experiments with an IW cell memory and fine grain size $(<45 \mu \mathrm{m})$ gave results most consistent with thermodynamic calculations. The IOF experimental results for olivine separates from Salta, Springwater, and Eagle Station fall within one log unit of the iron-wüstite oxygen buffer (IW). While these measurements may provide only an upper limit to the IOF of the pallasites, they correlate with the compositions of the olivine and metal in these samples: Salta, the most reduced pallasite studied (IW $-0.5 \log f \mathrm{O}_{2}$ ), contains $\mathrm{Fa}_{12.5}$ and $\mathrm{Fe}_{90.5} \mathrm{Ni}_{9.0}$; Springwater, of intermediate redox state $(\sim \mathrm{IW})$, contains $\mathrm{Fa}_{18.0}$ and $\mathrm{Fe}_{87.5} \mathrm{Ni}_{12.1}$; Eagle Station, the most oxidized sample (IW $+0.5 \log f \mathrm{O}_{2}$ ), contains $\mathrm{Fa}_{20.5}$ and $\mathrm{Fe}_{85.0} \mathrm{Ni}_{14.6}$. Electron microbeam characterization of the starting materials and run products from these experiments have shown that olivine is the only phase present. Thermodynamic calculations of redox equilibria involving equilibrium pallasite assemblages are in good agreement with our experimental results and provide a lower limit to pallasite redox stability; others involving disequilibrium assemblages, suggest that pallasites experienced localized, late-stage oxidation and reduction effects. Consideration of the redox buffer metal-olivine-orthopyroxene utilizing calculated Eucrite Parent Body (EPB) mantle phase compositions indicates that small redox gradients may have existed in the EPB. Such gradients may have produced strong compositional variation within the EPB. In addition, there is apparently significant redox heterogeneity in the source area of Eagle Station Trio (EST) pallasites and Bocaiuva iron meteorites.
\end{abstract}

\section{INTRODUCTION}

PALlASITES ARE STONY-IRON meteorites consisting predominantly of olivine and iron-nickel metal. There have been numerous studies completed on the mineralogy (e.g., MASON, 1963; BUSECK, 1977), geochemistry (e.g., SCOTT, 1977a; DAVIS, 1977), and texture (e.g., SCOTT, 1977b; OHTANI, 1983) of pallasites. Pallasites are generally thought to be pieces of the core-mantle boundary of a small asteroid-sized planet (LOVERING, 1957; RINGWOOD, 1959, 1961; FISH et al., 1960; ANDERS, 1964; BUSECK and GOLDSTEIN, 1969; GREENBERG and CHAPMAN, 1984). On the basis of petrologic, geochemical, and isotopic characteristics, HED (howardite, eucrite, and diogenite) meteorites, mesosiderites, pallasites, and IIIAB iron meteorites are all thought to be pieces of the same parent body or bodies (Eucrite Parent Body, or EPB) (SCOTT, 1977a; STOLPER, 1977; CLAYTON and MAYEDA, 1978; CLAYTON et al., 1986; LONGHI and PAN, 1988). This assemblage of meteorites provides a remarkable core to crust cross-section of a small planet, and therefore offers an opportunity to study oxidation states and geochemical zonation in the interior of such a protoplanet and understand how these two properties

\footnotetext{
* Present address: Department of Geology and Geophysics, University of California, Berkeley, CA 94720 , USA.

${ }^{\dagger}$ Present address: Department of Geology and Geophysics, University of New England, Armidale, NSW, Australia 2351.
}

may have evolved. Calculations indicate a refractory element, chondritic bulk composition for the EPB (DREIBUS et al., 1977; MORGAN et al., 1978; DREIBUS and WÄNKE, 1980). Experiments and calculations show that some eucrites formed by partial melting of an olivine-orthopyroxene-plagioclasespinel source (EPB mantle), apparently in equilibrium with a metallic phase, leaving an olivine-rich residue (STOLPER, 1977; JONES, 1984); other eucrites may have formed by fractionation of these primary liquids (WARREN and JERDE, 1987; WARREN, 1985). Depletion of W, P, Mo, and Co in eucrites with respect to chondritic abundances suggests that a metal core had formed in the EPB before the partial melting or fractionation event that formed the eucrites (NEWSOM and DRAKE, 1982, 1983; NEWSOM, 1985; HEWINS and NEWSOM, 1988). In summary, it appears that the EPB evolved in the following manner: (1) accretion as a homogeneous, volatiledepleted, near-chondritic body; (2) segregation of metal from silicate material (core formation), involving large degrees of partial melting; (3) partial melting of the EPB mantle to produce primitive and fractionated eucritic liquids at the surface; and (4) fragmentation of the EPB and eventual impact of some of the pieces on Earth. If the partial melting in step 2 was as severe as suggested by NEWSOM (1985), HEWINS and NEWSOM (1988), and TAYLOR (1989), then this stage of EPB evolution may have resulted in a magma ocean and an $\mathrm{Mg}$ rich residue (pallasite core-mantle boundary); if so, this explains why the "EPB mantle" is not represented in the meteorite population. 
Rigorous characterization of redox equilibria within the pallasites is important for modeling geochemical processes such as differentiation and core formation that took place during the early stages of planetary growth. Given the simple and persistent mineralogy of the pallasites (Table 1), their redox nature should be well constrained: however, $f \mathrm{O}_{2}-7$ relations are reported that differ by $1.5 \log$ units at $900^{\circ} \mathrm{C}$ for samples that are nearly identical in composition (OLSEN and FREDRIKSSON, 1966; HOLMES and ARCULUS, 1983; BRETT and SATO, 1984) (Fig. 1). IOF measurements on olivine separates from Salta (main group), Springwater (anomalous group), and Eagle Station (Eagle Station Trio group, or EST: groupings after BUSECK, 1977; SCOTT, 1977a: DAVIS, 1977) were completed in order to explore some of the discrepancies between values obtained in earlier studies, to search for systematic behavior of IOF with respect to metal-olivine compositions. and to explore the redox nature of the coremantle boundary of this small planetary body.

\section{EXPERIMENTAL}

\section{Background}

The fundamental principles involved in electrochemical studies were described in detail by SATO (1971) and are summarized here. Differences in the chemical potential of oxygen between two electrodes separated by a stabilized zirconia electrolyte will generate an emf at high temperatures according to the Nernst equation

$$
E=\frac{R T}{4 F} \ln \frac{f \mathrm{O}_{2} \text { sample }}{f \mathrm{O}_{2} \text { reference }}
$$

where $E$ is the emf in $\mathrm{mV}, T$ is the temperature in $\mathrm{K}, R$ and $F$ are the gas and Faraday constants, respectively, and the factor 4 represents the number of electrons involved in the cell reaction $\left(\mathrm{O}_{2}=2 \mathrm{O}^{2-}\right)$. The electrical potential across the cell (emf) is a measure of the difference in the chemical potential of oxygen between the two electrodes. If the temperature and the $f \mathrm{O}_{2}$ of the reference electrode are known, the $f \mathrm{O}_{2}$ of the sample electrode can be determined by measuring the emf across the cell. The $T-f \mathrm{O}_{2}$ range in which $\mathrm{Y}_{2} \mathrm{O}_{3}$ (or $\mathrm{CaO}$ )-stabilized $\mathrm{ZrO}_{2}$ acts as essentially a pure $\mathrm{O}^{2-}$ conductor is well known and encompasses most geologically relevant conditions (SATO, 1971).

\section{Equipment}

The experimental apparatus used in this study is a double-opposed cell configuration with a gas-bridging atmosphere, similar to that

Table 1: PALIASITE MINERALOGY*

\begin{tabular}{|c|c|}
\hline Major & Minor \\
\hline Taenite $\mathrm{Fe}_{<0 . \mathrm{B}^{,}}{ }^{\mathrm{Ni}}>0.2$ & Chromite $(\mathrm{Mg}, \mathrm{Fe})(\mathrm{Cr}, \mathrm{Al})_{2} \mathrm{O}_{4}$ \\
\hline Kamacite $\sim \mathrm{Ee}_{0.93^{,}} \mathrm{Ni}_{0.07}$ & Schreibersite $(\mathrm{Fe}, \mathrm{Ni})_{3} \mathrm{P}$ \\
\hline Olivine $(\mathrm{Mg}, \mathrm{Fe})_{2} \mathrm{SiO}_{4}$ & Stanfieldite $\mathrm{Ca}_{4}(\mathrm{Mg}, \mathrm{Fe}, \mathrm{Mn})_{5}\left(\mathrm{PO}_{4}\right)_{6}$ \\
\hline Troilite Fes & Whitlockite $\mathrm{Ca},(\mathrm{Mg}, \mathrm{Fe})(\mathrm{Na}, \mathrm{K})\left(\mathrm{PO}_{4}\right)_{7}$ \\
\hline & Farringtonite $(\mathrm{Mg}, \mathrm{Fe})_{9}\left(\mathrm{PO}_{4}\right)_{6}$ \\
\hline & Orthopyroxene (Mg, Fe) $\mathrm{SiO}_{3}$ \\
\hline & Clinopyroxene $\mathrm{Ca}(\mathrm{Mg}, \mathrm{Fe}) \mathrm{Si}_{2} \mathrm{O}_{6}$ \\
\hline
\end{tabular}

* from Buseck (1977) and Buseck and Holosworth (1977)

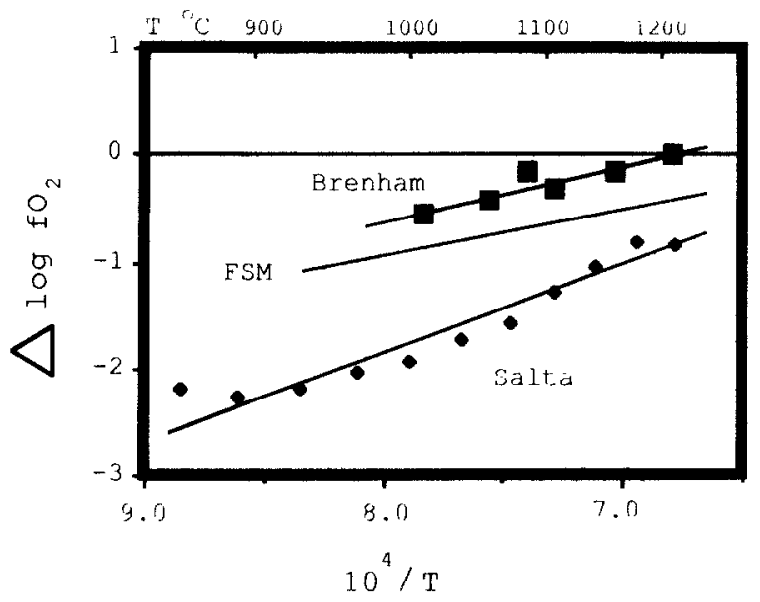

FIG. 1. Previous studies: Intrinsic oxygen fugacity measurements of Brenham (HOLMES and ARCULUS, 1983) and Salta (BRETT and SATO, 1984), and thermodynamic calculations (FSM = farringtoniteschreibersite-metal) of OLSEN and FREDRIKSSON (1966) and BUSFCK and HOLDSWORTH (1977) for pallasite meteorites. Linear regression values are presented in Table 6 . These results are shown relative to the iron-wuistite (IW) buffer of DARKEN and GURRY (1945).

described by SATO (1971), and is housed in a Deltech DT-31-VT, $\mathrm{MoSi}_{2}$ element-equipped furnace (Fig. 2). Several recent studies have described this apparatus (LOUREIRo et al., 1990; KersTING et al., 1989 ) in detail. The components are housed in an alumina muffle

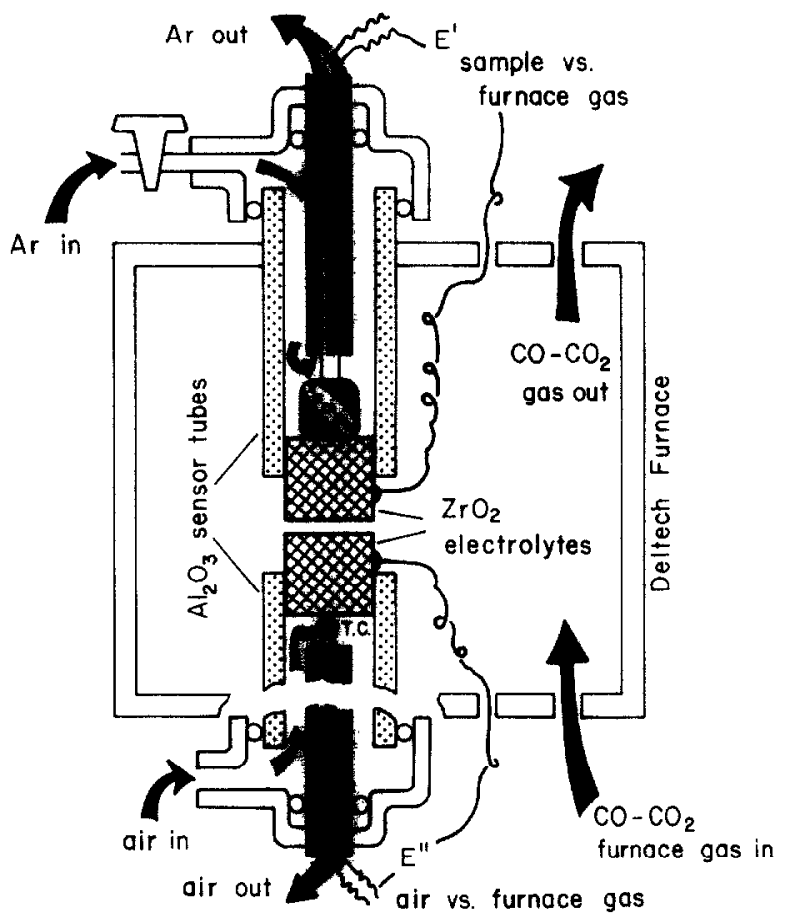

FIG. 2. Schematic diagram of the experimental apparatus modified from ARCULUS and DELANO (1981a). $E^{\prime}$ represents the emf generated by the difference in $\mathrm{O}_{2}$ potential between the sample unknown and the $\mathrm{CO}-\mathrm{CO}_{2}$ furnace gas. $E^{\prime \prime}$ represents the emf generated by the difference in $\mathrm{O}_{2}$ potential between the known reference gas (air) and the $\mathrm{CO}-\mathrm{CO}_{2}$ furnace gas. Samples are held in a platinum capsule, which is wrapped with one electrical lead. The capsule is in electrical contact with the zirconia sensor via a platinum chip which sits between (T.C. = thermocouple). 
tube, which is capped by water-cooled brass fittings; these fittings incorporate gas, zirconia sensor, and electric lead ports which are equipped with gas tight, O-ring, and cajon-fitting seals. $\mathrm{CO}-\mathrm{CO}_{2}$ gas mixtures are produced by use of two flowmeters, which allow control of the relative proportions of each gas in the mixture. The gas-mix ratios were checked against the tables of DeINES et al. (1974). The two stabilized zirconia solid electrolytes were manufactured under license from CSIRO of Australia by Ceramic Oxide Fabricators Pty. Ltd., under the name of "SIRO ${ }_{2}$ sensors." The $\mathrm{SIRO}_{2}$ sensor is a solid yttria-stabilized $\mathrm{ZrO}_{2}$ plug that is permanently bonded via a high-temperature, eutectic weld $\left(\mathrm{Al}_{2} \mathrm{O}_{3}-\mathrm{ZrO}_{2} \mathrm{mix}\right)$ to a high purity alumina sensor tube. Temperature was measured with a calibrated type-S thermocouple (Pt-Pt $\left.\mathbf{P t}_{\mathbf{8}} \mathbf{R h}_{\mathbf{1 3}}\right)$. The lower cell contains air as a reference gas. The upper sensor contains the sample of interest, usually between 75 to $125 \mathrm{mg}$ of powdered material loaded in an iron-saturated $\mathrm{Pt}$ closed-end tube. The platinum capsule is wrapped with one electrical lead, and electrical contact is assured by a $P t$ chip (not shown in Fig. 2) which sits between the capsule and the zirconia sensor. The emfs generated by the difference in electrical potential between the sample and the gas-bridging atmosphere, and the gasbridging atmosphere and the reference cell, are measured by a Keithley model \#614 electrometer and a Simpson model \#464 (series 3) digital multimeter, respectively.

\section{Calibration}

The performance of this apparatus and comparative behavior of the $\mathrm{SIRO}_{2}$ versus other forms of $\mathrm{ZrO}_{2}$ electrolyte have been reported in previous studies (LOUREIRO et al., 1990; KERSTING et al., 1989; HOLMES et al., 1989); calibration against the known buffer standard,

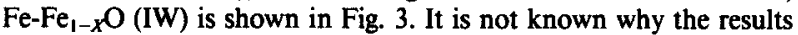
from one run lie below the reference line of DARKEN and GURRY (1945). The results from the four other IW runs fall within 0.05 log units of each other. The electrochemical determinations of HOLMES et al. (1986) are also shown for reference. In general, the apparatus reproduces accepted $f \mathrm{O}_{2}$ values within $\pm 0.05 \log$ units of the IW buffer.

\section{Procedures}

Pallasite olivines were gently plucked from their metal matrix with dental picks and small chisels. The freshest olivines were ground $d r y$ in an agate mortar and separated by size with various metal mesh sieves. For all three pallasites, the freshest grains which are clear or

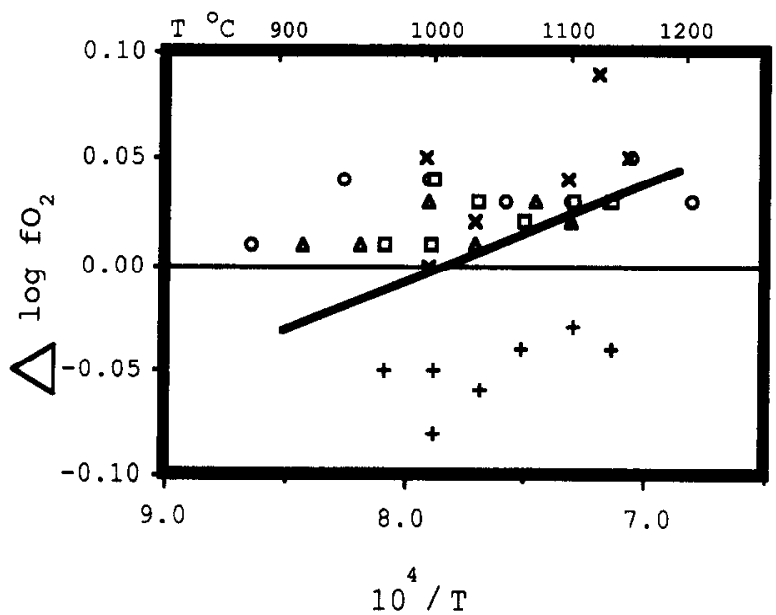

Fig. 3. Measured $\mathrm{fO}_{2}$ for IW, plotted relative to the results of DARKEN and GURRY (1945). Different symbols correspond to five different experiments. Solid line represents IW measurements of HoLmes et al. (1986). Linear regression values for previous IW determinations are presented in Table 6. Note the expanded scale in this figure. light green in color, with no signs of weathered or oxidized material on the surface or along internal fractures, were hand-picked with tweezers using a stereo microscope and then separated for further grinding to a finer grain size (either between 45 and $125 \mu \mathrm{m}$, or less than $45 \mu \mathrm{m}$ ). No organic chemicals or solutions were utilized in the sample preparation steps. Approximately $75-125 \mathrm{mg}$ were used in each experimental run.

The procedures employed in this study utilize reversible measurements as described by LoUREIRo et al. (1990) and KERSTING et al. (1989). The experimental apparatus is designed to allow an equilibrium approach from both reducing and oxidizing starting conditions in separate experiments. The ability to control the initial redox memory of the sample cell is a consequence of the presence of $450 \mathrm{ppm}$ $\mathrm{Fe}$ in the alumina tubes hosting the $\mathrm{ZrO}_{2}$ electrolyte. It has previously been shown that during a run with an IW sample, the trace of $\mathrm{Fe}$ present in the $\mathrm{Al}_{2} \mathrm{O}_{3}$ tube reaches equilibrium with this redox state (LOUREIRo et al., 1990). Subsequent runs with a blank employing the same sensor continue to give IW signals, showing an internal redox memory. Similarly, an oxidized memory can be produced by baking the sample cell with impure Ar of $\log f \mathrm{O}_{2}=-3$ for a few hours at elevated $\left(1000^{\circ} \mathrm{C}\right)$ temperatures. In this case, the $\mathrm{Fe}$ in the alumina sample holder is oxidized. In both cases, the weak memory is a short-term effect which will wear off after several hours at high temperatures, and can be overwhelmed by samples of high Fe content or buffering capacity that are introduced into the cell (LOUREIRO et al., 1990). Utilizing this design and approach, the following procedures were adopted for this study, with a few exceptions that will be described later:

1) A sample of iron + wüstite (IW) is loaded into the cell and run at high temperatures to test the performance of the apparatus against a standard redox electrode (air) and to impose a reduced memory on the sample sensor.

2) A geological sample is loaded at room temperature into the sensor possessing the IW memory. Any air that was loaded with the sample is then forced out of the cell by flowing scrubbed argon (cleaned of organics, water, and then trace oxygen, by passing the Ar over copper coils at $\sim 800^{\circ} \mathrm{C}$ ) into the sample cell overnight, before sealing the sample sensor. The scrubbed argon has a measured $\log f \mathrm{O}_{2}$ close to that of IW at any given temperature and thus is very close to the weak memory in the sample cell. Upon heating, the sample overrides the IW memory in the cell and approaches its equilibrium redox state from the direction of the IW buffer. The sample is then cycled up and down temperature between 850 and $1150^{\circ} \mathrm{C}$, as the emf is measured at several specific temperatures.

3) The sensor is emptied of its sample and baked at $\sim 1000^{\circ} \mathrm{C}$ in air in order to remove any remnant of a memory from steps 1 and 2. The empty sensor is filled with unscrubbed argon and is then sealed and monitored for drift in the emf. This "blank run" is designed to check the mechanical integrity of the apparatus and to impose a weak, oxidized memory (measured $\log f \mathrm{O}_{2} \sim-3$ at $1000^{\circ} \mathrm{C}$ ) on the sensor.

4) A new aliquot of the same sample used in step 2 is loaded into the sensor and flushed with unscrubbed argon at room temperature, before sealing the sensor. Upon heating, the sample approaches its equilibrium redox state from an oxidized direction and can be cycled up and down temperature again in order to obtain measurements at various temperatures.

This four-step procedure allows the sample to approach equilibrium from both an oxidized direction and a reduced direction, thus achieving reversed equilibrium (LOUREIRO et al., 1990; KERSTING et al., 1989).

\section{Revised Procedures}

The freshest and the most abundant olivine was obtained from Salta. Two aliquots each were prepared of $45-125 \mu \mathrm{m}$-sized olivines and olivines $<45 \mu \mathrm{m}$ in size; these aliquots were run according to steps 1 to 4 above (Fig. 4). The results vary over a range of two log $\mathrm{fO}_{2}$ units, although theoretically one would expect all four runs to be identical. This variation may be due to the following three effects: 


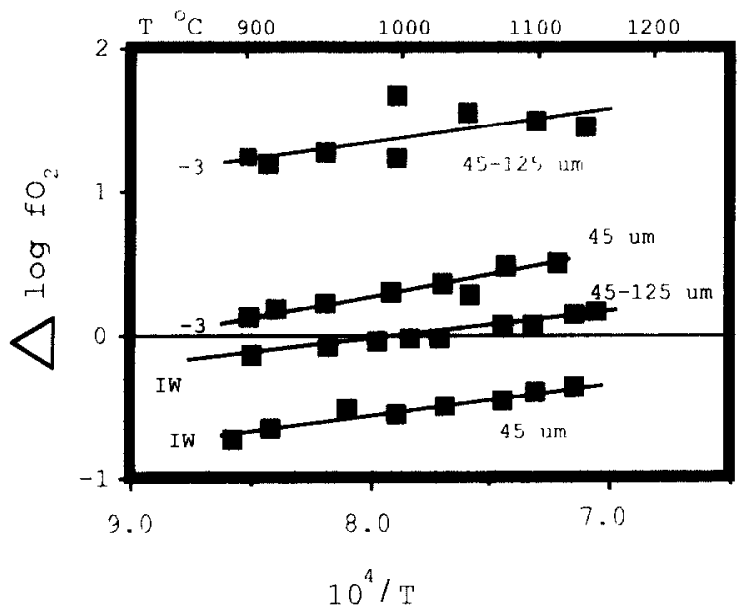

FIG. 4. Grain size effects in olivine IOF measurements: measured $f \mathrm{O}_{2}$ for Salta olivine, plotted relative to IW of DARKEN and GURRY (1945). Two experiments were performed on coarse-grained olivines $(45-125 \mu \mathrm{m})$ and two on fine-grained olivines $(<45 \mu \mathrm{m})$. For each grain size, one experiment was started with an oxidized cell memory (in the presence of impure Ar with $\log \mathrm{fO}_{2}=-3$ ), and the second experiment was started with a reduced cell memory (in the presence of scrubbed Ar with $\left.\log f \mathrm{O}_{2} \sim \mathrm{IW}\right)$. The most reduced run shown includes points $6-12$ only from Table 4 . Linear regression values are presented in Table 6 .

1) Length of experiment. The first three runs, which are the three most oxidized, lasted less than $48 \mathrm{~h}$ each; the fourth run, the most reduced, lasted nearly a week and slowly equilibrated below IW (Fig. 5).

2) Grain size. The reduction in grain size from $125 \mu \mathrm{m}$ to $<45 \mu \mathrm{m}$ produces a large increase in olivine surface area available for reaction in the sample and thus potentially an increase in reaction rate. The finer-grained aliquots have equilibrated at more reducing conditions, which suggests that they reacted to a greater degree than the coarse-grained samples.

3) Memory. The buffering capacity of a pallasite olivine may not be robust enough to react with all of the oxygen in the unscrubbed argon of steps 3 and 4 ; hence, the olivines may react only enough to reduce the $\mathrm{fO}_{2}$ but never actually achieve equilibrium.

Such phenomena are consistent with all four runs in Fig. 4, as the longest experiments, the finest-grain size aliquots, and the IW memory runs all equilibrated at the lowest $f \mathrm{O}_{2}$ values. The procedure adopted for the experimental runs of the three pallasites makes allowances for all three effects-experiments were continued for about one week to allow the sample to equilibrate. samples were crushed and sieved so that only olivine grains $<45 \mu \mathrm{m}$ were included in the experiments, and all experiments were started from an IW memory so that the sample had enough buffering capacity to achieve equilibrium. The stability of pallasites below the IW buffer limits our ability to obtain reversed experimental results; that is, we can approach equilibrium from the oxidized (IW) direction, but we are not yet able to impose a memory on the sample sensor that is more reducing than IW. Unlike the terrestrial samples studied by LOUREIRO et al. (1990) and KERSTING et al. (1989), we cannot approach equilibrium from a more reduced direction than the samples themselves and our measurements thus represent an upper limit on pallasite redox stability.

\section{Microbeam Analysis}

Pallasite thin sections and olivine starting materials and run products were examined with a Hitachi (S-570) scanning electron microscope (SEM) and an automated CAMFCA electron microprobe at the University of Michigan's Electron Microbeam Analysis Laboratory. Standards used on the microprobe were: for olivine - synthetic uvarovite $(\mathrm{Cr})$, Marjalahti olivine $(\mathrm{Fe}, \mathrm{Mg}, \mathrm{Si})$, Evans apatite $(\mathrm{P})$, wollastonite (Ca), and Broken Hill rhodonite ( $\mathrm{Mn}$ ); for phesphateEvans apatite $(\mathrm{Ca}, \mathrm{P})$, Tiburon albite $(\mathrm{Na})$, Broken Hill rhodonite $(\mathrm{Mn})$, synthetic ferrosilite (Fe), synthetic enstatite ( $\mathrm{Mg}, \mathrm{Si}$ ). and Gotthard potassium feldspar (K): for phosphide-synthetic indium phosphide (P). iron metal (Fe), and nickel metal (Ni): for metd-BCS Steel Standards No. 5, 6, 7. 8, 9, 10. For olivine, phosphate, and phosphide analyses, operating conditions were $15 \mathrm{kV}$ accelerating voltage and $10 \mathrm{nA}$ heam current with a point beam $(\sim 1 \mu \mathrm{m}$ diameter). For determinations of $\mathrm{CaO}$ in olivine, operating conditions of 15 $\mathrm{kV}, 10 \mathrm{nA}$ with a point beam and $100 \mathrm{~s}$ counting times were utilized. For four analyses of $\mathrm{CaO}$ on one grain. average background $: 5.87$ $\mathrm{c} / \mathrm{s}$ and average peak $=8.83 \mathrm{c} / \mathrm{s}$, which corresponds to an average wt $\% \mathrm{CaO}$ of $540 \mathrm{ppm}$. For determinations of $\mathrm{Si}$ in metal phases. operating conditions were $15 \mathrm{kV}$ accelerating voltage. $150 \mathrm{n} \wedge$ beam current. a rastered beam at $80 \mathrm{kX}$ magnification. and 100 s counting times. Peak counts for $\mathrm{Si}$ in metal (both kamacite and tienite) were statistically indistinguishable from background for all three pallasite samples. Detection limits for $\mathrm{Si}$, according to the equations presented in GOLDS rEIN et al. (1981) and at 95\% degree of confidence, range from 16 to $70 \mathrm{ppm}$ for the standards used in this study (they contain 0.24-1.00 wt\% Si). Representative olivine analyses from both the natural samples $(\mathrm{N})$ and run products $(\mathrm{R})$ are presented in Table ?; phosphate and phosphide analyses are presented in Table ?.

\section{RESLIITS}

The IOF results are presented in Fig. 6 and Table 4 for the Salta. Springwater, and Eagle Station pallasites. The results fall within one $\log f \mathrm{O}_{2}$ unit of the IW buffer, and correlate with metal and olivine compositions in each meteorite (Fig. 7). Salta, the most reduced sample, contains $\mathrm{Fa}_{125}$ and $\mathrm{Fe}_{90.5} \mathrm{Ni}_{9.0}$ in the metal phase. Springwater, of intermediate redox state, contains $\mathrm{Fa}_{180}$ and $\mathrm{Fe}_{87.5} \mathrm{Ni}_{12,0}$ in the metal. Eagle Station. the most oxidized sample, contains $\mathrm{Fa}_{20.3}$ and $\mathrm{Fe}_{85.0} \mathrm{Ni}_{14.6}$ in metal (Fig. 7). Such correlations are consistent with variations in $f \mathrm{O}_{2}$ buffered by the assemblage metal-olivine (MO) (Figs. 8, 9, and 10). Although pallasites do not contain primary pyroxene or silica, these results are similar to variations in $f \mathrm{O}_{2}$ buffered by the assemblages metal-olivineorthopyroxene (MOO) and quartz-metal-olivine (QMO), with varying dilutions of fayalite and ferrosilite. Thus, the trend from reduced to oxidized results correlates well with the observed mineral compositions in these three samples (Fig. 7).

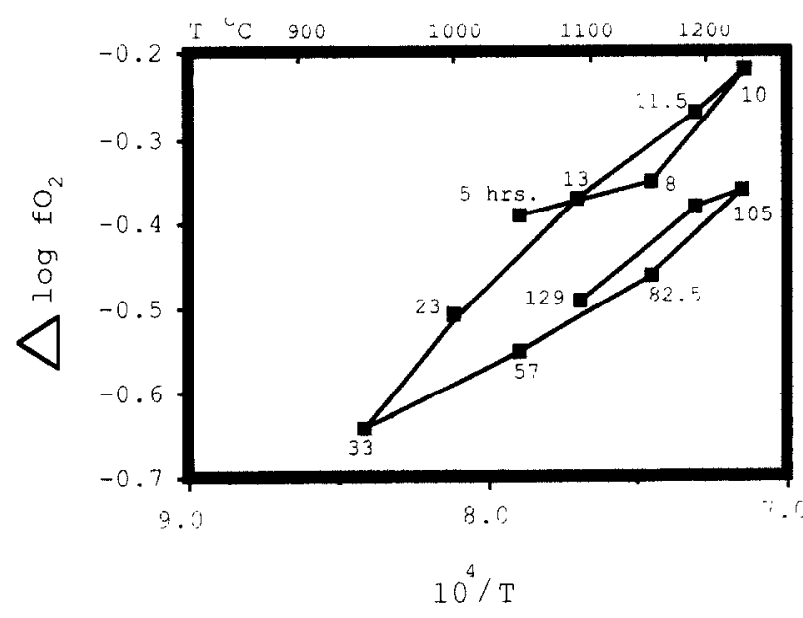

FIG. 5. Effect of experiment duration: measured $f \mathrm{O}_{2}$ for Salta olivine (points $1-12$ in Table 4), plotted relative to IW of DARKEN and GURRY (1945). Numbers next to a datum represent the number of hours passed since the beginning of the experiment. 
Table 2: Representative olivine microprobe analyses

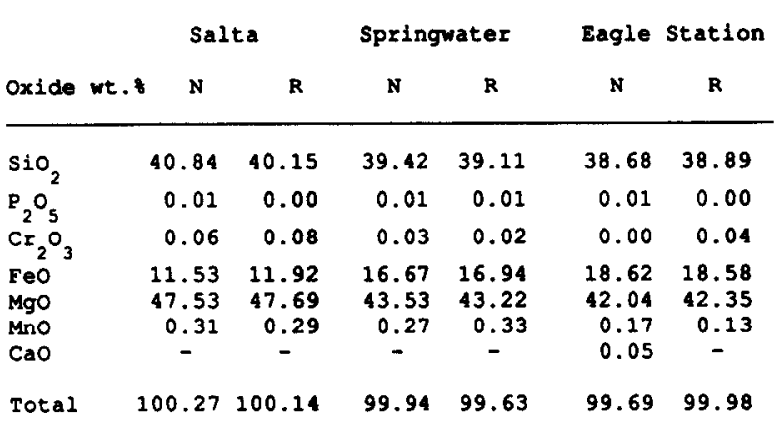

Normalized to three cations

$\begin{array}{lclllll}\text { Si } & 1.007 & 0.991 & 0.998 & 0.995 & 0.992 & 0.993 \\ \text { P } & - & - & - & - & - & - \\ \text { Cr } & 0.001 & 0.002 & - & - & - & - \\ \text { Fe } & 0.238 & 0.246 & 0.353 & 0.360 & 0.399 & 0.395 \\ \text { Mg } & 1.748 & 1.755 & 1.643 & 1.638 & 1.603 & 1.609 \\ \text { Mn } & 0.006 & 0.006 & 0.006 & 0.007 & 0.004 & 0.003 \\ \text { Ca } & - & - & - & - & 0.002 & - \\ \text { Total } & 3.000 & 3.000 & 3.000 & 3.000 & 3.000 & 3.000\end{array}$

$N$ = Natural olivine

$R=$ Run product olivine

Microprobe analyses of the pre- and post-run olivines are virtually indistinguishable (Table 2). Apparently no iron has been lost from the sample to the Pt-capsule. Scanning electron

Table 3: Springwater phosphate and phosphide analyses

\begin{tabular}{|c|c|c|c|c|c|}
\hline oxide wt. & 1 & 2 & 3 & Element & 4 \\
\hline $\mathrm{P}_{2} \mathrm{O}_{5}$ & 51.16 & 44.16 & 47.51 & $\mathrm{Fe}$ & 73.84 \\
\hline $\mathrm{SiO}_{2}$ & 0.03 & 0.01 & 0.02 & $\mathbf{N i}$ & 10.47 \\
\hline $\begin{array}{l}\mathrm{MgO} \\
\mathrm{FeO} \\
\mathrm{MnO} \\
\mathrm{CaO} \\
\mathrm{Na}_{2} \mathrm{O}\end{array}$ & $\begin{array}{r}44.24 \\
4.20 \\
0.16 \\
0.09 \\
0.00\end{array}$ & $\begin{array}{r}3.62 \\
0.47 \\
0.04 \\
47.34 \\
2.78\end{array}$ & $\begin{array}{r}22.17 \\
3.03 \\
0.51 \\
25.57 \\
0.00\end{array}$ & $P$ & 15.58 \\
\hline $\mathrm{K}_{2} \mathrm{O}$ & 0.02 & 0.05 & 0.00 & & \\
\hline Totals & 99.81 & 98.48 & 98.80 & & 99.89 \\
\hline
\end{tabular}

Phosphates calculated to number of oxygens in formula.

\begin{tabular}{lrrrll}
$\mathrm{P}$ & 5.840 & 6.853 & 5.886 & $\mathrm{Fe}$ & 2.640 \\
$\mathrm{Si}$ & 0.005 & 0.002 & 0.004 & $\mathrm{Ni}$ & 0.368 \\
$\mathrm{Mg}$ & 8.894 & 0.989 & 4.836 & $\mathrm{P}$ & 1.004 \\
$\mathrm{Fe}$ & 0.465 & 0.072 & 0.371 & & \\
$\mathrm{Mn}$ & 0.018 & 0.007 & 0.063 & & \\
$\mathrm{Ca}$ & 0.013 & 9.292 & 4.009 & & \\
$\mathrm{Na}$ & 0.000 & 0.988 & 0.000 & & \\
$\mathrm{~K}$ & 0.004 & 0.012 & 0.000 & & \\
Total & 15.239 & 18.215 & 15.169 & & 4.012 \\
\hline
\end{tabular}

\footnotetext{
1 - farringtonite (24 oxygens)

2 - whitlockite (28 oxygens)

3 = stanfieldite (24 oxygens)

4 = schreibersite
}

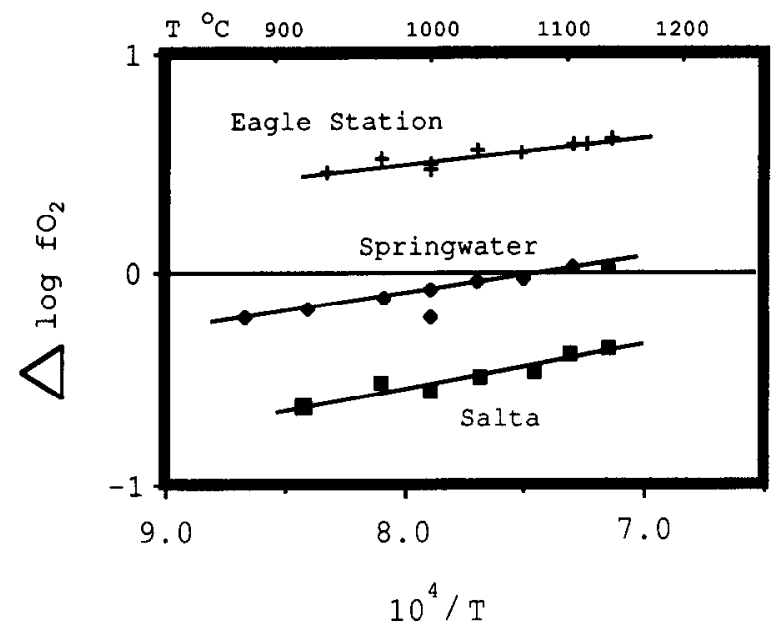

Fig. 6. Measured $\mathrm{fO}_{2}$ for Salta, Springwater, and Eagle Station olivines ( $<45 \mu \mathrm{m}$ grain size and IW memory), plotted relative to IW of DARKEN and GURRY (1945). Results fall within one log unit and correlate with olivine and metal compositions. Linear regression values are presented in Table 6.

microscopy (SEM) revealed that no additional phases were formed in the run products as a result of the experimental treatment. Previous studies on olivines subjected to reducing conditions at high temperatures have shown that metal can precipitate at grain boundaries and edges (BOLAND and DUBA, 1986) of olivine grains. No such precipitates were observed in the pallasite olivine run products.

\section{THERMODYNAMIC CALCULATIONS}

\section{Mineralogy}

Salta

The mineralogy of this main group pallasite (pallasite classification after DAVIS, 1977, and SCOTT, 1977a) is relatively simple. In addition to the abundant olivine, metal, troilite, and schreibersite, Salta contains a minor amount of whitlockite (BUSECK, 1977). The assemblage metal-olivine (MO) is sensitive to variations in ambient $\mathrm{fO}_{2}$ :

$$
2 \mathrm{Fe}+\mathrm{Si}+2 \mathrm{O}_{2}=\mathrm{Fe}_{2} \mathrm{SiO}_{4} .
$$

The amount of Si in kamacite and taenite in all three pallasites in this study is below our detection limits of $15-70 \mathrm{ppm}$. Similarly, the amount of $\mathrm{Si}$ in kamacite of the IIIAB iron meteorites Cape York and Bella Roca was found to be below detection limits of $30 \mathrm{ppm}$ by electron microprobe analysis (EMPA) (WAI and WASSON, 1969). A Si content of $15 \mathrm{ppm}$ $\left(X_{\mathrm{Si}}=3.0 \times 10^{-5}\right)$ was used in the MO calculations for Salta, Springwater, and Eagle Station, and thus represents a lower limit on $\log \mathrm{fO}_{2}$ calculations of this equilibrium assemblage, since the $\mathrm{fO}_{2}$ increases with decreasing Si-content (Fig. 11). Three main group pallasites (Ahumada, Admire, Marjalahti) contain orthopyroxene $\left(\mathrm{Fs}_{11.4-11.6}\right)$ which occurs in complex symplectitic intergrowths containing olivine, troilite, phosphate, and metal (BUSECK, 1977). The composition of the metal $\left(\mathrm{Fe}_{90.5} \mathrm{Ni}_{9.0}\right)$ and olivine $\left(\mathrm{Fa}_{12}\right)$ in these pallasites is identical to those in Salta. Despite the textural evidence for 
Table 4: Data from IOF runs

Number $K \quad 1 / K * 10^{4} \quad \log \mathrm{EO}_{2}$ Time (hrs.)

1) SALTA: Iw memory; 45 - $125 \mu \mathrm{m}$ grain size

$\begin{array}{llll}1299.2 & 7.70 & -14.51 & 240 \\ 1366.4 & 7.32 & -13.35 & 180 \\ 1414.2 & 7.07 & -12.57 & 195 \\ 1397.4 & 7.16 & -12.83 & 174 \\ 1342.9 & 7.45 & -13.69 & 560 \\ 1277.8 & 7.83 & -14.81 & 175 \\ 1223.4 & 8.17 & -15.82 & 160 \\ 1157.7 & 8.64 & -17.16 & 185 \\ 1254.1 & 7.97 & -15.24 & 140 \\ 1299.2 & 7.70 & -14.47 & 125\end{array}$

2) SALTA: $\log \mathrm{fO}_{2}=-3$ memory; $45-125 \mu m$ grain size

$\begin{array}{llll}1267.1 & 7.89 & -13.31 & 195 \\ 1319.1 & 7.58 & -12.61 & 545 \\ 1369.4 & 7.30 & -11.89 & 735 \\ 1408.4 & 7.10 & -11.33 & 125 \\ 1221.9 & 8.18 & -14.50 & 100 \\ 1186.8 & 8.43 & -15.21 & 70 \\ 1266.4 & 7.90 & -13.73 & 320\end{array}$

3) SALTA: $\log \mathrm{fO}_{2}=-3$ memory; <45 um grain size

$\begin{array}{llll}1265.6 & 7.90 & -14.55 & 330 \\ 1368.7 & 7.31 & -12.83 & 240 \\ 1343.6 & 7.44 & -13.29 & 240 \\ 1298.2 & 7.70 & -14.11 & 635 \\ 1265.6 & 7.90 & -14.71 & 195 \\ 1221.9 & 8.18 & -15.55 & 180 \\ 1186.8 & 8.43 & -16.25 & 180 \\ 1319.1 & 7.58 & -13.86 & 560\end{array}$

4) SALTA: IW memory; <45 $4 \mathrm{~m}$ grain size

$\begin{array}{llll}1266.4 & 7.90 & -15.38 & 285 \\ 1340.7 & 7.46 & -14.15 & 170 \\ 1398.9 & 7.15 & -13.17 & 50 \\ 1368.7 & 7.31 & -13.65 & 60 \\ 1298.2 & 7.70 & -14.83 & 60 \\ 1234.2 & 8.10 & -16.06 & 540 \\ 1188.4 & 8.42 & -17.04 & 2730 \\ 1266.4 & 7.90 & -15.54 & 1380 \\ 1340.3 & 7.46 & -14.27 & 1467 \\ 1398.5 & 7.15 & -13.32 & 1315 \\ 1368.7 & 7.31 & -13.76 & 376 \\ 1300.1 & 7.69 & -14.92 & 863\end{array}$

5) SPRINGWATER: IW memory; <45 $\mu m$ grain size

$\begin{array}{llll}1267.9 & 7.89 & -15.18 & 1280 \\ 1399.6 & 7.15 & -12.93 & 975 \\ 1369.4 & 7.30 & -13.35 & 300 \\ 1331.8 & 7.51 & -13.97 & 875 \\ 1299.7 & 7.69 & -14.49 & 430 \\ 1235.8 & 8.09 & -15.64 & 875 \\ 1189.1 & 8.41 & -16.56 & 155 \\ 1153.0 & 8.67 & -17.32 & 376 \\ 1267.9 & 7.89 & -15.04 & 810\end{array}$

6) EAGLE STATION: IW memory: $<45 \mathrm{\mu m}$ grain size

$\begin{array}{llll}1267.9 & 7.89 & -14.46 & 480 \\ 1331.7 & 7.51 & -13.39 & 840 \\ 1401.1 & 7.14 & -12.30 & 35 \\ 1370.9 & 7.29 & -12.75 & 1445 \\ 1299.7 & 7.69 & -13.87 & 85 \\ 1235.0 & 8.10 & -15.01 & 70 \\ 1201.2 & 8.33 & -15.69 & 135 \\ 1267.9 & 7.89 & -14.48 & 660 \\ 1380.4 & 7.24 & -12.59 & 675\end{array}$

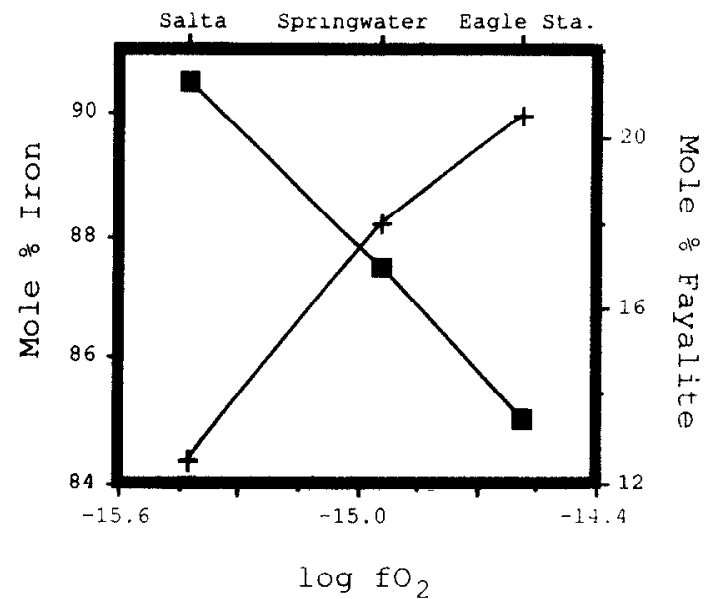

FIG. 7. Correlation of metal (mol\% Fe; squares) and olivine (mol\% fayalite; crosses) compositions with IOF measurements $\left(\log f \mathrm{O}_{2}\right)$ at $1000^{\circ} \mathrm{C}$ for Salta, Springwater, and Eagle Station pallasites. The mineral compositions for each meteorite are given below the meteorite name on the top border. Olivine compositions were determined in this study (see Table 2), and metal compositions were determined by SCOTT $(1977 \mathrm{a})$. These correlations are consistent with variations in $f \mathrm{O}_{2}$ buffered by equilibria involving metal and olivine such as MO, MOO, QMO (or IQF) with varying dilutions of fayalite, ferrosilite, and Fe metal. See text for further discussion.

disequilibrium, the assemblage metal-orthopyroxene-olivine (MOO) is a redox buffer that can be applied to these main group pallasites:

$$
2 \mathrm{Fe}+2 \mathrm{FeSiO}_{3}+\mathrm{O}_{2}=2 \mathrm{Fe}_{2} \mathrm{SiO}_{4} .
$$

\section{Springwater}

The mineralogy of this anomalous group pallasite is more complex than most. Originally described by NININGER (1932),

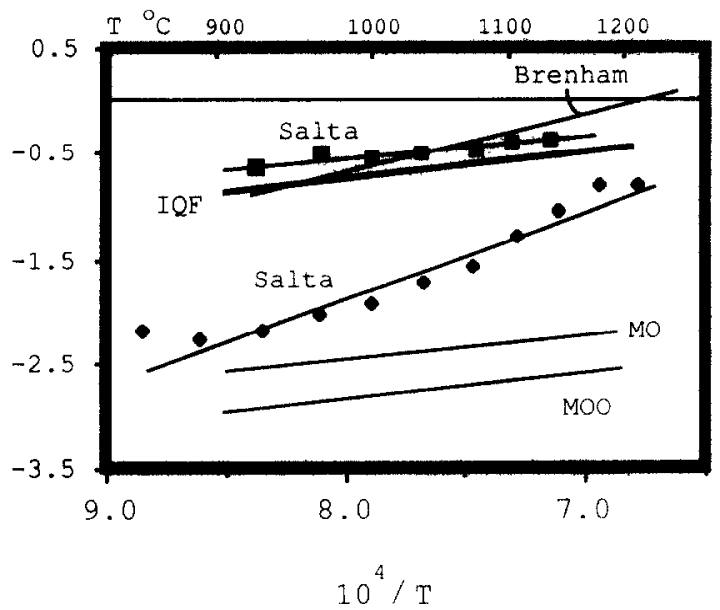

FIG. 8. Comparison of our experimental results for Salta (squares) and previous IOF measurements of Salta (diamonds, BRETT and SATO, 1984) and Brenham (HOLMES and ARCULUS, 1983) with thermodynamic calculations of the equilibria MOO (metal-orthopyroxene-olivine) and MO (metal-olivine), using pallasite mineral compositions in the calculations (see Table 5 for data sources). IQF (ironquartz-fayalite) as determined by O'NEILL (1987). Linear regression values are presented in Table 6 . 


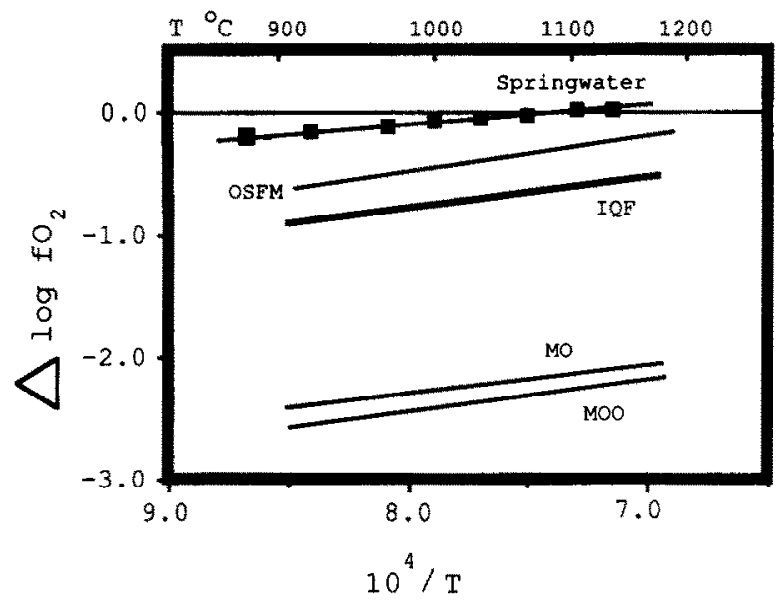

FIG. 9. Comparison of experimental results for Springwater (squares) with thermodynamic calculations of the equilibria OFSM (olivine-farringtonite-schreibersite-metal), MO, and $\mathrm{MOO}$ using Springwater mineral compositions in the calculations (see Table 5 for data sources). IQF as determined by O'NEILL (1987). Linear regression values are presented in Table 6 .

Springwater was later shown to contain orthopyroxene, farringtonite, stanfieldite, whitlockite, and phosphoran olivine in addition to abundant metal $\left(\mathrm{Fe}_{87.5} \mathrm{Ni}_{12.1}\right)$, olivine $\left(\mathrm{Fa}_{18}\right)$, troilite, and schreibersite (DUFRESNE and RoY, 1961; BUSECK, 1977; BUSECK and HOLDSWORTH, 1977). Farringtonite is quite abundant ( 4.2 modal\%) and occurs as large rounded masses between olivine and metal (BUSECK, 1977). Whitlockite occurs as intergrowths within the stanfieldite in our sample, suggesting that these phosphates have unmixed from a homogeneous phosphate upon cooling (Fig. 12). Analyses of these phosphates are presented in Table 3. Schreibersite occurs as both lamellae within the metal and distinct grains

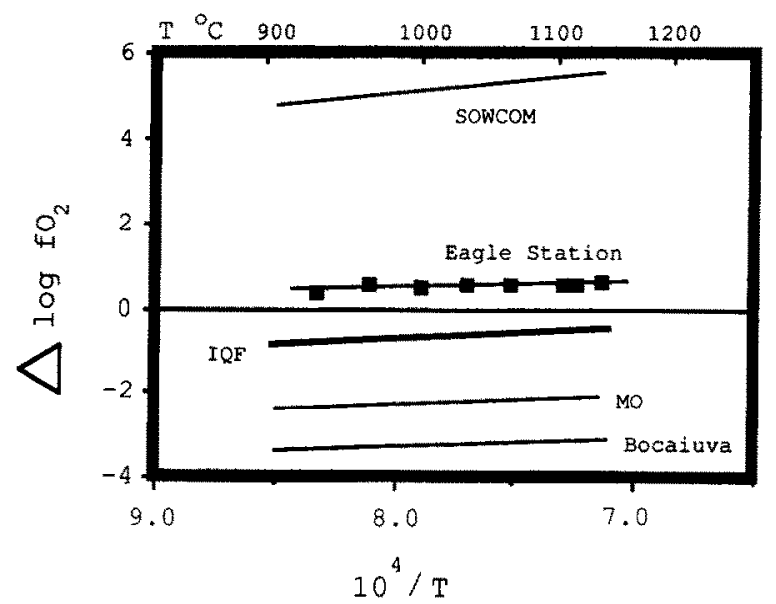

FIG. 10. Comparison of our experimental results for Eagle Station (squares) to calculations of the equilibria SOWCOM (schreibersiteolivine-whitlockite-clinopyroxene-orthopyroxene-metal) and MO, using Eagle Station mineral compositions (DAVIS and OLSEN, 1989), and MOO, using Bocaiuva iron meteorite phase compositions (MALvIN et al., 1985) (see Table 5 for data sources). IQF as determined by O'NEILL (1987). Linear regression values are presented in Table 6.

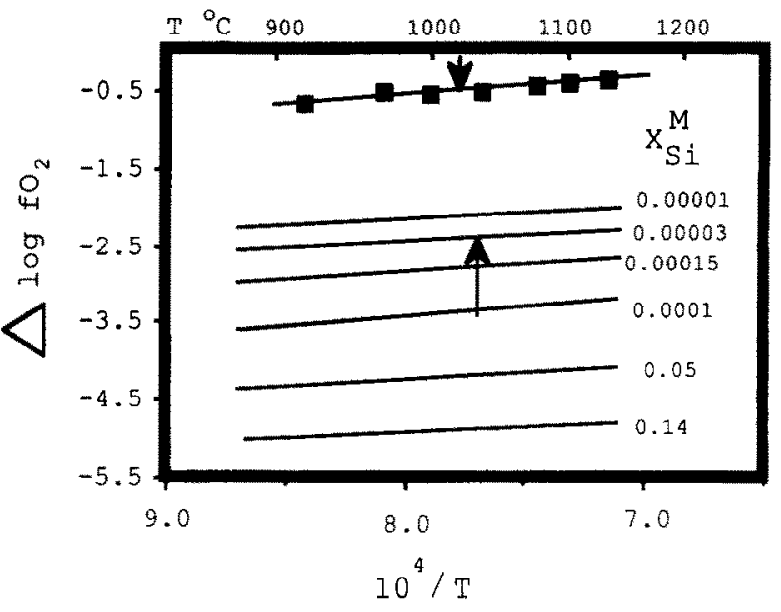

FIG. 11. Shift in the position of the redox buffer MO with varying $X_{\mathrm{Si}}$ and constant $X_{\mathrm{Fe}}$ and $X_{\mathrm{Fe}_{2} \mathrm{SiO}_{4}}$ (set at Salta compositions). Position of this buffer moves in a more oxidizing direction with smaller dilutions of Si in the metal; thus it serves as a lower limit on pallasite redox stability. Solid line and squares represent our experimental results for Salta. Sources of thermodynamic data in Table 5 .

associated with olivine, farringtonite, stanfieldite, whitlockite, chromite, and troilite (Fig. 12); analyses are presented in Table 3. Phosphoran olivine (4-5 wt $\% \mathrm{P}_{2} \mathrm{O}_{5} ; \mathrm{Fa}_{18.5}$ ) occurs adjacent to P-free olivines and shares either a sharp contact, within

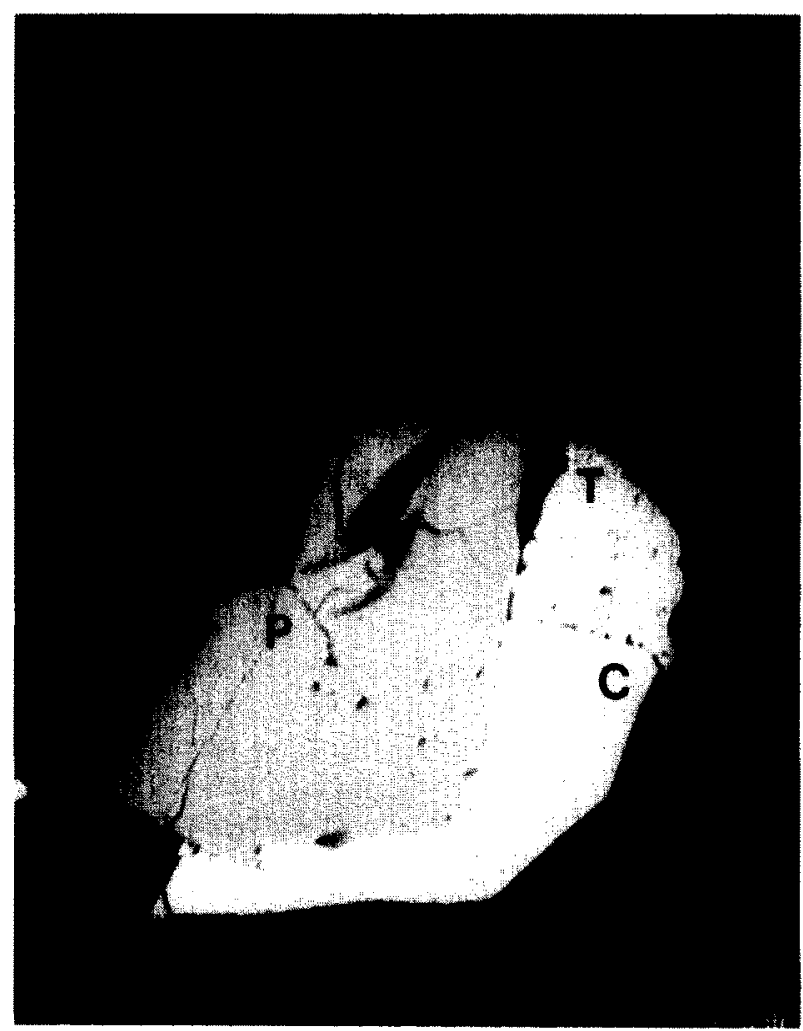

FIG. 12. Backscattered electron image of troilite (T), chromite (C), schreibersite (P), farringtonite (F), and coexisting stanfieldite (S) and whitlockite (W). These phases are enclosed by olivine, which is out of the field of view. Scale bar at bottom right. 
the same grain, or a mutual grain boundary (BUSECK, 1977). The phosphoran olivines are few in number and generally only several hundred microns in size (BUSECK, 1977; BUSECK and CLARK, 1984). The orthopyroxene $\left(\mathrm{Fs}_{16.6}\right)$ occurs in complex symplectitic intergrowths of troilite, kamacite, and phosphate, along the margin of olivine grains. The pyroxenes are also rare and the fine intergrowths are no larger than 500 $\mu \mathrm{m}$ in width (BUSECK, 1977). These unusual phases buffer oxygen fugacity in two redox equilibria. One involves olivineschreibersite-farringtonite-metal (OSFM) (OLSEN and FREDRIKSSON, 1966):

$$
3 \mathrm{Mg}_{2} \mathrm{SiO}_{4}+4 \mathrm{Fe}_{3} \mathrm{P}+8 \mathrm{O}_{2}
$$

$$
=3 \mathrm{Fe}_{2} \mathrm{SiO}_{4}+2 \mathrm{Mg}_{3}\left(\mathrm{PO}_{4}\right)_{2}+6 \mathrm{Fe},
$$

and these phases are apparently in equilibrium. The other involves metal-orthopyroxene-olivine (MOO), but this may be a disequilibrium assemblage, based on the symplectitic textures. Thermodynamic characterization of these equilibria can be directly compared to our experimental results.

\section{Eagle Station}

Like Springwater, Eagle Station's mineralogy is more complex than that of most pallasites. In addition to abundant olivine $\left(\mathrm{Fa}_{20.5}\right)$ and metal $\left(\mathrm{Fe}_{85.0} \mathrm{Ni}_{14.6}\right)$, there occurs minor chromite, stanfieldite, whitlockite, clinopyroxene, orthopyroxene, troilite, and schreibersite (BUSECK, 1977; BUSECK and HOLDSWORTH, 1977; DAVIS and OLSEN, 1989). The assemblage schreibersite-olivine-whitlockite-clinopyroxeneorthopyroxene-metal (SOWCOM) is a redox buffer:

$$
\begin{aligned}
& 2 \mathrm{Fe}_{3} \mathrm{P}+4 \mathrm{CaMgSiO}_{4}+5 / 2 \mathrm{O}_{2} \\
&=\mathrm{Ca}_{3}\left(\mathrm{PO}_{4}\right)_{2}+\mathrm{CaMgSi}_{2} \mathrm{O}_{6}+\mathrm{MgSiO}_{3}+6 \mathrm{Fe} .
\end{aligned}
$$

The amount of $\mathrm{CaO}$ in olivine has been determined by EMPA to be $0.03-0.056 \mathrm{wt} \%$; this is in contrast to values of 30 and $845 \mathrm{ppm}$ reported in BUSECK and GoLDSTEIN (1969). The value of $0.054 \mathrm{wt} \% \mathrm{CaO}\left(X_{\mathrm{CaMgSiO}_{4}}=0.001\right)$, determined in olivines in our sample of Eagle Station, was utilized in these calculations. Many of these phases occur in the complex intergrowths and thus may represent a later stage reequilibration than the primary pallasite oxidation state in which we are interested.

\section{Thermodynamic Data}

All of the calculations in this section utilize the expression $\Delta G=R T \ln K$, where $K$ is made up of the products of the various activities presented in Table 5 . An attempt has been made to utilize internally consistent thermodynamic data in the calculation of the four redox equilibria described in the previous section. In several cases, however, this is not possible due to limited data for a few phases.

\section{OSFM}

Gibbs free energy data for farringtonite and forsterite are tabulated in CHASE et al. (1985); data for schreibersite are tabulated in KUBASCHEWSKI and ALCOCK (1979). Neither of these sources tabulate data for fayalite, so those of RoB-
INSON et al. (1983) were used; consequently, our calculations for OSFM involve data from three sources by necessity. Activity-composition $(a-x)$ relations for olivine were taken from SACK and GHIORSO (1989).

\section{$M O O$ and $M O$}

Gibbs free energy data for fayalite and ferrosilite at high temperatures are presented in ROBINSON et al. (1983) and are used in the MOO and MO equilibria. Activity-composition relations for Fe-rich olivine and orthopyroxene were taken from SACK and GHIORSO (1989) for these calculations. Activity coefficients for $\mathrm{Fe}-\mathrm{Si}$ solutions (MO) were taken from the electrochemical determinations of SAKAO and ELLIOT (1975) for $T=1400 \mathrm{~K}$ and FRUEHAN (1970) for $T=1800$ K. Activity coefficients for Fe-Ni-Co solutions (MOO) were taken from the experimental determinations of CONARD et al. (1978) and FRASER and RAMMENSEE (1982).

\section{SOWCOM}

Gibbs free energy data for schreibersite were taken from KUBASCHEWSKI and ALCOCK (1979); whitlockite data are available only in ROBIE et al. (1978); ROBINSON et al. (1983) is the source for enstatite; thermodynamic data for the phases forsterite, diopside, and monticellite have recently been reevaluated by SHARP et al. (1986) and thus are utilized in this calculation.

Application of Gibbs free energy data $2 \sigma$ values given in ROBINSON et al. (1983) to equilibria such as MO and MOO result in insignificant variations of $0.01 \log f \mathrm{O}_{2}$ units in these calculations.

\section{Results}

The redox equilibria outlined above have been calculated using the thermodynamic, activity, and composition data, which are summarized in Table 5, and the results appear in Figs. 8, 9, 10, 11 and 13 .

\section{Salta}

Calculations for the MO reaction lies approximately 1.5 $\log f \mathrm{O}_{2}$ units below our electrochemical measurements for Salta (Fig. 8); the position of this equilibrium in $f \mathrm{O}_{2}-T$ space varies with $\mathrm{Si}$-content such that at lower wt $\% \mathrm{Si}(<15 \mathrm{ppm})$ the equilibrium moves closer to IW. Since Salta metal must contain less than $15 \mathrm{ppm} \mathrm{Si}$, the results of this calculation are consistent with $\mathrm{MO}$ representing a lower limit on pallasite redox state (Fig. 8). The MOO calculation, however, lies approximately $2.5 \log \mathrm{fO}_{2}$ units below our experimental results. The orthopyroxene occurs in symplectitic intergrowths with olivine, troilite, phosphate, and metal and appears to be a disequilibrium assemblage (BUSECK, 1977). It is quite possible that this assemblage (MOO) formed during subsolidus reduction.

\section{Springwater}

Calculations for OSFM lie approximately $1 / 2 \log f \mathrm{O}_{2}$ unit below the results for Springwater (Fig. 9). MO lies approximately $1.5 \log \mathrm{fO}_{2}$ units below experimental results for 


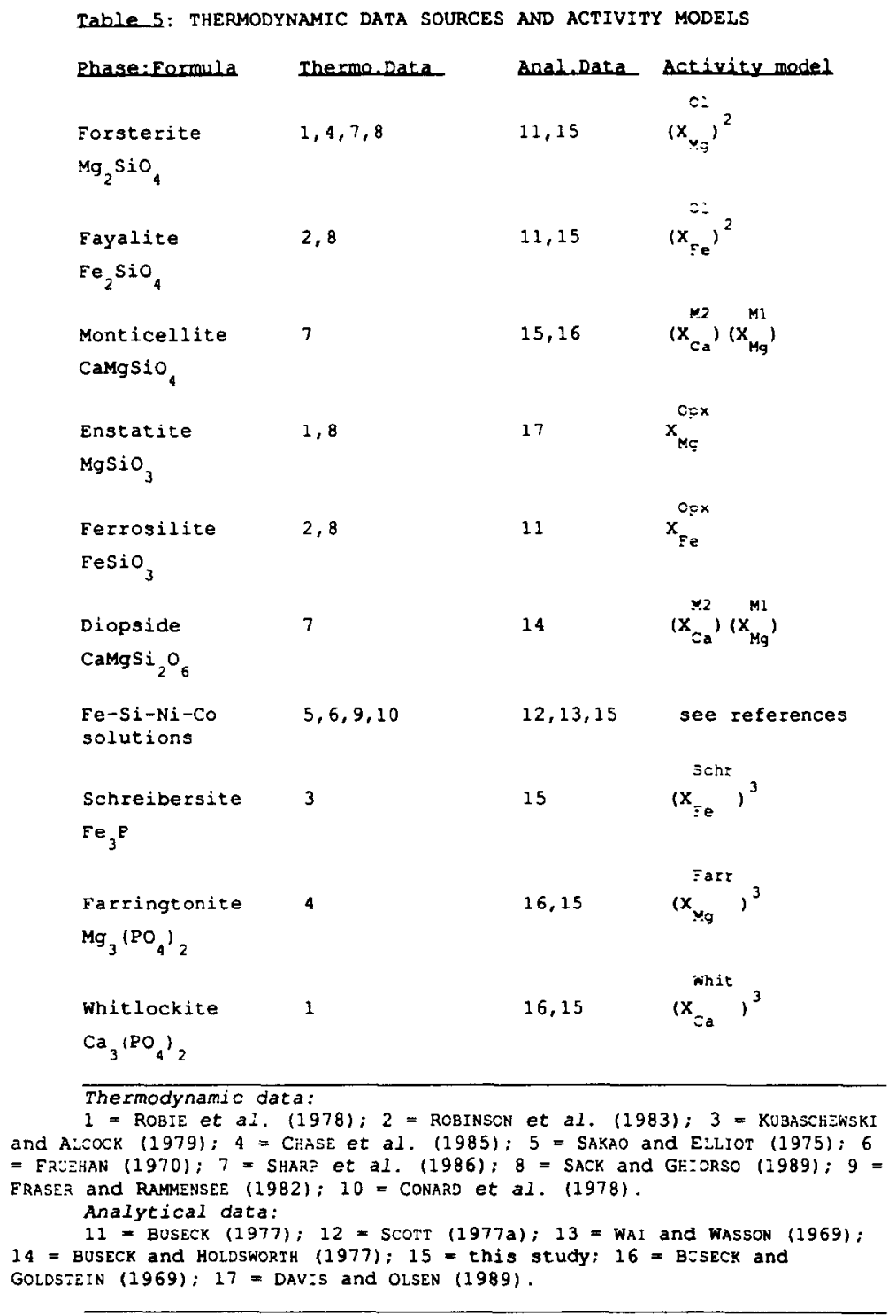

Springwater, which, as with Salta, is consistent with MO, representing a lower limit to pallasite redox stability. These calculations are in good agreement with the electrochemical measurements and are also consistent with our electrochemical results, representing an upper limit on pallasite redox state. The MOO calculation, again, lies approximately 2.5 $\log \mathrm{fO}_{2}$ units below our experimental results, which suggests that this assemblage appeared in anomalous pallasites as a result of subsolidus reduction.

\section{Eagle Station}

MO lies roughly $2.5 \log f \mathrm{O}_{2}$ units below the experimental results for Eagle Station, which, as with Salta and Springwater, is consistent with $\mathrm{MO}$, representing a lower limit on pallasite redox stability. Calculations of the equilibrium SOWCOM lie 5 to $6 \log \mathrm{fO}_{2}$ units above our experimental results for Eagle Station (Fig. 10). Occurrence of this assemblage in symplectitic intergrowths suggests that it must have formed in a subsolidus oxidation reaction after the dominant metalolivine texture equilibrated.

\section{DISCUSSION}

\section{The Redox State of Main Group and Anomalous Pallasites}

Previous determinations of the redox state of pallasites, including electrochemical measurements and thermodynamic calculations, do not provide a particularly well-constrained stability field for the pallasites. Previous electrochemical results for Salta (BRETT and SATO, 1984, linear regressions presented in Table 6.) fall below the IQF buffer (Fig. 8); in addition, the slope of their results is steeper than the slope of IQF and our experimental and calculated results. Previous electrochemical results for Brenham (HOLMES and ARCULUS, 1983) lie close to the present results for Salta (Fig. 8); both of these samples are main group pallasites. Any thermodynamic calculations relevant to pallasites are plagued by the presence of only one silicate phase, olivine, so that $a_{\mathrm{SiO}_{2}}$ cannot 
Table 5: Linear Regression Data:

EOR EQUATIONS CF THE FCRM: $-\log$ fO $=M *\left\{10^{\circ} / \mathrm{T}\right\}-\mathrm{B}$

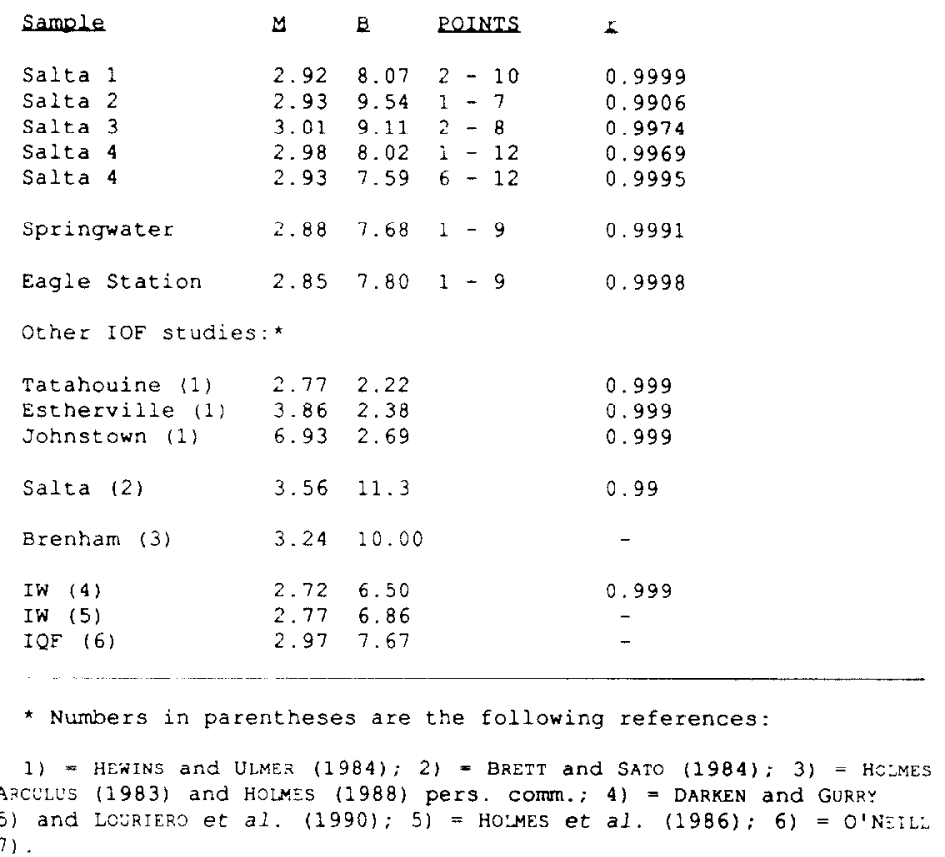

be directly fixed. Consideration of redox buffers such as IQF and MOO, therefore, can only serve as limits on pallasite redox stability, since there is no primary orthopyroxene or

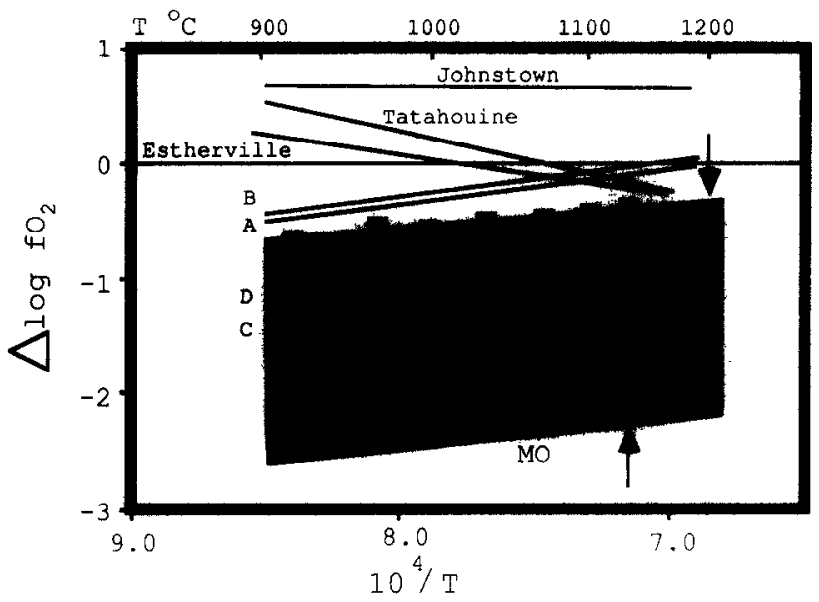

FIG. 13. Comparison of our experimental results (squares) and thermodynamic calculations (MO) for Salta to experimental results of HEWINS and ULMER (1984) for the meteorites Estherville, Johnstown, and Tatahouine. Shading represents area between upper and lower limits of main group pallasite stability. These measurements are shown relative to the IW buffer of DARKEN and GURRY (1945). Also shown are calculations of the redox buffer MOO for four different EPB mantle compositions: (A) $X_{\mathrm{Fe}}=0.40, X_{\mathrm{Fa}}^{\mathrm{Ol}}=X_{\mathrm{Fs}}^{\mathrm{Opx}}=0.35$; (B) $X_{\mathrm{Fe}}=0.40, X_{\mathrm{Fa}}^{\mathrm{O}}=X_{\mathrm{Fs}}^{\mathrm{Opx}}=0.20 ;$ (C) $X_{\mathrm{Fe}}=0.90 ; X_{\mathrm{Fa}}^{\mathrm{O}}=X_{\mathrm{Fs}}^{\mathrm{Opx}}=0.35$; and (D) $X_{\mathrm{Fe}}=0.90, X_{\mathrm{Fa}}^{\mathrm{O}}=X_{\mathrm{Fs}}^{\mathrm{Opx}}=0.20$. Mantles A and B contain Fe-poor (and hence Ni-rich) metal, while mantles $\mathrm{C}$ and $\mathrm{D}$ contain relatively Fe-rich metal, which is similar in composition to metal in main group pallasites and IIIAB irons. See text for discussion of results. Linear regression values are presented in Table 6. quartz. Taking our experimental results for Salta as an upper limit on main group pallasite redox stability and our thermodynamic calculations of the reaction $\mathrm{MO}$ as a lower limit, it seems that main group pallasites equilibrated between IW and IQF-1. Such a range is consistent with previous experimental results of BRETT and SATO (1984) and HoLMES and ARCULUS (1983), and the absence of primary orthopyroxene in main group and anomalous pallasites. Previous calculations involving the assemblage olivine-schreibersite-farringtonitemetal in Springwater (OLSEN and FREDRIKSSON, 1966; OLSEN and FUCHS, 1967; BUSECK and HOLDSWORTH, 1977) are almost identical to those here, despite our use of a more recent set of thermodynamic data (Table 5). Our electrochemical measurements and thermodynamic calculations (OSFM) for Springwater are in good agreement, differing by $<0.5 \log \mathrm{fO}_{2}$ units (Fig. 9). It is apparent from these results that phosphorus is a useful sensor of redox conditions in the pallasites. The redox state of both main group and anomalous (such as Springwater) pallasites is apparently tightly constrained between IW and IQF-1.

\section{The Eagle Station Trio and "Parent Body"}

The experimental results for Eagle Station, $1 / 2 \log f \mathrm{O}_{2}$ unit above the IW buffer, suggest that the EST pallasites equilibrated at more oxidizing conditions than the main group pallasites; this has previously been suggested by others on the basis of higher Fe/Mn ratios in olivines (DAVIS, 1977) and high Fe-content of olivine and chromite (SCOTT, 1977a). Recent oxygen isotopic analyses of silicate inclusions from the Bocaiuva iron meteorite (MALVIN et al,, 1985) suggest a possible genetic relationship between EST pallasites and Bocaiuva-type irons. Some of the silicate inclusions in this iron, 
however, are very magnesian olivine and orthopyroxene $(\mathrm{MgO} /(\mathrm{MgO}+\mathrm{FeO})=\mathrm{Mg} \#=0.90$ to 0.96). Use of these phase compositions in thermodynamic calculations of $\mathrm{MOO}$ results in a $T-f \mathrm{O}_{2}$ curve that is $3 \log f \mathrm{O}_{2}$ units below IW (Fig. 10) and therefore $\sim 3.5 \log f \mathrm{O}_{2}$ units below our experimental results for Eagle Station. Thus, if Eagle Station and Bocaiuva are from the same parent body or area of the solar system, compositional and redox heterogeneity must be present, unlike the olivine-metal assemblages in main-group pallasites. Further analysis of these silicate-bearing iron meteorites and their relation to the EST pallasites is warranted.

\section{The Eucrite Parent Body (EPB)}

Non-cumulate eucrites have been classified into three types, based on Ti vs. Mg\# diagrams: "Main Group," "Stannern Trend," and "Nuevo Laredo Trend" (BVSP, 1981; WARREN and JERDE, 1987). The Stannern Trend eucrites are thought to have formed by varying degrees of partial melting, while the Nuevo Laredo Trend eucrites are thought to be products of fractionally crystallized liquids (BVSP, 1981; WARREN and JERDE, 1987; LONGHI and PAN, 1988). Partial melting experiments (STOLPER, 1977), trace element partitioning calculations (JONES, 1984), and trace element modeling (MORGAN et al., 1978; CONSOLMAGNO and DRAKE, 1977) indicate that the EPB mantle would have an $\mathrm{Mg} \#=0.65-0.67$, while fractional crystallization models (WARREN and JERDE, 1987; DREIBUS and WÄNKE, 1980) show that the EPB mantle would have a $\mathrm{Mg} \#=0.80-0.88$.

If main group pallasites and eucrites are from the same parent body, this body could have a mantle with a $\mathrm{Mg} \#$ of either 0.65 or 0.80 , adjacent to core-mantle boundary pallasites with a $\mathrm{Mg} \#$ of $0.80-0.88$. One might assume that similar $\mathrm{Mg \# s}$ in mantle and core-mantle boundary would indicate a body with a narrowly constrained redox state, which is consistent with IOF measurements of diogenite and mesosiderite clasts (HEWINS and ULMER, 1984) and main group pallasites (this study), which cluster around IW (Fig. 13). Different $\mathrm{Mg \# s}$ in mantle and core-mantle boundary, however, would indicate a body with redox gradients. Since olivine compositions and $\mathrm{Mg \# s}$ alone can not sense the $\mathrm{fO}_{2}$ of a system, consideration of the redox buffer metal-olivine-orthopyroxene (MOO) may help to constrain the $f \mathrm{O}_{2}-T$ relations prevalent in the EPB mantle.

HEDs all contain native iron (DUKE, 1965; GOOLEY and MOORE, 1976; HEWINS, 1979), and basaltic achondrites are generally thought to be saturated with respect to a metallic phase (BVSP, 1981). The origin of this metal, however, may be late- or post-crystallization, as suggested by BRETT (1976) for lunar mare basalts and recently shown by PALME et al. (1988) for the Camel Donga eucrite. Oxygen isotope analyses of free silica phases in the eucrites Nuevo Laredo, Pasamonte, Juvinas, and Moore County (TAYLOR et al., 1965) are extraordinarily high (12-14\%o relative to SMOW), which suggests that the silica is also a post-crystallization phase. The iron metal and silica could be produced in a subsolidus reduction reaction (PALME et al., 1988) such as

$$
\mathrm{FeSiO}_{3}=\mathrm{Fe}+\mathrm{SiO}_{2}+1 / 2 \mathrm{O}_{2}
$$

Since the composition of the metal in the EPB mantle is relatively unconstrained, $T-f \mathrm{O}_{2}$ relations for the buffer MOO have been calculated at four metal and silicate compositions: (A) $X_{\mathrm{Fe}}=0.40$ and $X_{\mathrm{Fa}}^{\mathrm{O}}=X_{\mathrm{Fs}}^{\mathrm{Opx}}=0.35$; (B) $X_{\mathrm{Fe}}=0.40$ and $X_{\mathrm{Fa}}^{\mathrm{O}}=X_{\mathrm{Fs}}^{\mathrm{Opx}}=0.20 ;(\mathrm{C}) X_{\mathrm{Fe}}=0.90$ and $X_{\mathrm{Fa}}^{\mathrm{Ol}}=X_{\mathrm{Fs}}^{\mathrm{Opx}}=0.35$; and (D) $X_{\mathrm{Fe}}=0.90$ and $X_{\mathrm{Fa}}^{\mathrm{O}}=X_{\mathrm{Fs}}^{\mathrm{Opx}}=0.20$ (DEER et al., 1964; Fig. 13). Both of the calculations at $X_{\mathrm{Fe}}=0.40$ (Mantles $A$ and B) lie slightly above our upper limit to pallasite stability (Fig. 13) and suggest that an EPB mantle with Fe-poor, Nirich metal will be more oxidized than the main group pallasite core-mantle boundary (for cither fractional crystallization or partial melting model). Calculations for Mantles $\mathrm{C}$ and $\mathrm{D}$ at $X_{\mathrm{Fe}}=0.90$ (the approximate metal composition of the isotopically and compositionally related IIIAB irons and main group pallasites) lie within our upper and lower limits on pallasite stability (Fig. 13) and suggest slight, if any, redox gradients. It is apparent that the metal composition dominates the position of these calculations in $T-\int \mathrm{O}_{2}$ space, rather than silicate $\mathrm{Mg \# s}$. As a result, these calculations do not strongly favor either the partial melting or fractional crystallization origin for the eucrites. Small but significant redox gradients, however, may have existed in an EPB with a mantle containing Ni-rich metal.

\section{CONCLUSIONS}

The following points should be reemphasized: first, there are considerable grain-size effects in IOF measurements (also noted by MATTIOLI and WOOD, 1988)-additional studies should be undertaken in order to investigate the extent of these effects; second, the redox state of pallasite meteorites correlates with olivine and metal composition; third, the redox state of main group and anomalous pallasites is constrained between IW and IQF-1; fourth, there is apparently significant redox heterogeneity in the source area of EST pallasites and Bocaiuva iron meteorites; and fifth, redox gradients would have been slight in an EPB with $\mathrm{Ni}$-rich metal in the mantle, with a mantle slightly more oxidized than the pallasite coremantle boundary. Redox gradients would have been slight in an EPB with Ni-poor metal in the mantle and indistinguishable from the pallasite core-mantle boundary redox state as defined in this work.

A more comprehensive understanding of redox gradients in parent bodies is essential in evaluating hypotheses of terrestrial core formation such as whether it was a process involving chemical equilibrium or disequilibrium, whether complete extraction of metal from silicate occurred, and the degree of $\mathrm{fO}_{2}$ evolution during planetary differentiation (ARCUlus and DELANO, 1981b; BRETT, 1984; JONES and DRAKE, 1986). Gradients can be produced or at least sensed by volatile species in the parent body such as $\mathrm{C}-\mathrm{CO}-\mathrm{CO}_{2}$ or $\mathrm{H}_{2}-\mathrm{H}_{2} \mathrm{O}$ equilibria (ARCULUS, 1985; SATO, 1978; BRETT and SATO, 1984). Small redox gradients (1 to $2 \log f \mathrm{O}_{2}$ units) may produce large compositional variations, especially in the range of pallasite redox stability, as demonstrated in calculations presented by ARCULUS et al. (1990).

Two problems must be resolved in order to evaluate the presence of redox gradients in the EPB. First, attempts should be made to better constrain the composition of the metal in the source region of the eucrites. An interesting study might include analyzing all metal phases in HEDs in detail and 
integrating this data with textural studies, rather than concentrating on specific HED meteorite types as in previous studies (DUKE, 1965; HEwINS, 1979). Second, reliable IOF measurements on eucrite samples should be obtained to compare with the existing data for diogenites. mesosiderites, and pallasites. The attempts of BRETT and SATO (1984) to obtain such measurements on Ibitira and Sioux County were confounded by sample powders which were ground in acetone and a sample that originally fell in the sea; therefore, the results were questionable. Samples selected for such study should be free of any post-crystallization phases, such as silica, native iron, and troilite, and should be fresh, unoxidized finegrained polyphase samples. Such a study may help to further constrain the redox nature of the EPB mantle and eucrite source, and thus would be of great interest. Knowledge or identification of mineral assemblages and/or volatile species which can produce redox gradients is crucial to understanding the processes of core formation and planetary differentiation. not only in the EPB, but also in Earth, Mars, Venus. Mercury, and the Moon.

Acknowledoments-Research was supported in part by NSF grant EAR-8417131 to R.J.A. NASA grant NAG 9-78 to J.W.D. and a University of Michigan Turner grant to K.R. The pallasite samples are part of the Perry Meteorite Collection of the University of Michigan, curated by D. R. Peacor and R. J. Arculus. All experiments were performed in J.W.D.'s laboratory at the State University of New York, Albany. The electron microprobe and scanning electron microscope were obtained through NSF grants EAR-82-12764 and BSR 83-14092, respectively. C. H. Henderson provided invaluable assistance in obtaining microprobe analyses. M. A. Cosca, E. J. Essene, R. D. Holmes, and A. B. Kersting provided constructive criticism. advice, and assistance in all stages of the project. We appreciate the comprehensive critical reviews provided by R. Brett, E. J. Essene, R. Hewins, and H. E. Newsom in draft and submittal stages of this manuscript.

\section{Editorial handling: R. A. Schmitt}

\section{REFERENCES}

ANDERS E. (1964) Origin, age and composition of meteorites. Space Sci. Rev. 3, 583-714.

ARCULUS R. J. (1985) Oxidation state of the mantle: past and present. Ann. Rev. Earth Planet. Sci. 13, 75-95.

ARCULUS R. J. and DELANO J. W. (1981a) Intrinsic uxygen fugacity measurements: Techniques and results for spinels from upper mantle peridotites and megacryst assemblages. Geochim. Cosmochim. Acta 45, 899-913.

ARCulus R. J. and Delano J. W. (1981b) Siderophile element abundances in the upper mantle: Evidence for a sulfide signature and equilibrium with the core. Geochim. Cosmochim. Acta 45 . $1331-1343$.

ARCULUS R. J., HOLMES R. D., POWELL R., and RIGHTER K. (1990) Metal-silicate equilibrium and core formation. In The Origin of the Earth. (eds. J. JONES and H. NEwSOM) (in press).

BOLAND J. N. and DUBA A. G. (1986) An electron microscope study of the stability field and degree of nonstoichiometry in olivine. $J$ Geophys. Res. 91, $4711-4722$.

BRETT R. (1976) Reduction of mare basalts by sulfur loss. Geochim Cosmochim. Acta 40, 997-1004.

BRETT R. (1984) Chemical equilibration of the Earth's core and upper mantle. Geochim Cosmochim. Acta 48, 1183-1188.

BRETT R. and SATO M. (1984) Intrinsic oxygen fugacity measurements on seven chondrites, a pallasite, and a tektite and the redox state of meteorite parent bodies. Geochim. Cosmochim. Acta 48, $111-120$

Buseck P. R. (1977) Pallasite meteorites-mineralogy, petrology, and geochemistry. Geochim. Cosmochim. Acta 41, 711-740.
BUSECK P. R. and CLARK J. (1984) Zaisho-a pallasite containing pyroxene and phosphoran olivine. Min. Mag. 48, 229-235.

BUSECK P. R. and GOLDSTEIN J. 1. (1969) Olivine compositions and cooling rates of pallasitic meteonites. Bull. Gol. $S \%$ fm. 80, 2141 2158.

BUSECK P. R. and HoLDSworTh E. (1977) Phosphate minerals in pallasite meteorites. Min. Mag. 41, 91-102

BVSP (BASAltic Volcanism Stud ProjeCt) (1981) Basaltic lo/ canism on the Terrestrial Planets. Pergamon Press.

Chase M. W., JR., Davies C. A., Downey J. R., JR. Frurip D. J., MCDONALD R. A., and SYVERUD A. N. (1985) JANAF Thermochemical Tables. 3rd ed.: I. Phy. Chem. Ref. Datu 14, 1-1856.

CLAYTON R. N. and MAYEDA T. K. (1978) Genetic relations between iron and stony meteorites. Earth Planet. Sci. Litt. 40, 168-174.

Clayton R. N.. MaYeda T. K.. PRINZ M.. NehrU C. E.. and Di:LANEY J. E. (1986) Oxygen isotope confirmation of a genetic association between achondrites and IIIAB iron meteorites. Lunar Planet. Sci. XVII. 141.

CONARD B. R., MCANENEY T. B., and SRIDHAR S. (1978) Thermodynamics of iron-nickel alloys by mass spectrometry. Met. Trans. $B$ 78, $463 \cdot 68$.

CONSOlmagno G. J. and Drake M. J. (1977) Composition and evolution of the eucrite parent body: Evidence from rare earth elements. Geochim. Cusmochim, fita 41, 1271-1282.

DARKEN L. S. and GURRY R. W. (1945) The system iron-oxygen: 1. The wüstite field and related equilibria. $J$ Amer (hem. Soc. 67 , 1398-1412.

Davis A. M. (1977) The cosmochemical history of the pallasites. Ph.D. dissertation, Yale University.

DAVIS A. M, and OLSEN E. J. (1989) The origin of phosphate minerals in the Eagle Station and Springwater pallasites. Lumar Planet. Sci. $X X, 220-221$.

DEER W. A. HowIE R. A.. and ZUSSMAN J. (1964) Rock Forming Minerals, lol. I. Ortho and Ring Silicates. Longmans, London.

Deines P.. NAFZiger R. H. Ulmer G. C.. and WoERMANN E. (1974) Temperature-oxygen fugacity tables for selected gas mixtures in the system $\mathrm{C}-\mathrm{H}-\mathrm{O}$ at one atmosphere total pressure. Bull. Earth Min. Si. 88.

DREIBUS G. and WÄNKE H. (1980) The bulk composition of the eucrite parent asteroid and its bearing on planetary evolution. $Z$. Noturforsch. 35A, 204-216.

DREIBIS G., KRUSE H., SPETTEL B., and WÄKE (1977) The bulk composition of the moon and the eucrite parent body. Proc. Lanar Sit. Conf. sth, 211-227.

DUFRESNE E. R. and ROY S. K. (1961) A new phosphate mineral from the Springwater pallasite. Geochim. Cosmochim. Acta 24. $198-205$.

DukE M. B. (1965) Metallic iron in basaltic achondrites. J. Geophys. Res. 70, 1523-1527.

FISH R. A. COLES G. G, and ANDERS E. (1960) The record in meteorites. 11I. On the development of meteorites in asteroidal bodies. Astrophys. J. 132, 243-258.

FRASER D. G. and RAMMENSEE W. (1982) Activity measurements by Knudsen Cell mass spectrometry-the system $\mathrm{Fe}-\mathrm{Co}-\mathrm{Ni}$ and implications for condensation processes in the solar nebula. Ge? chim. Cosmochm. Acta 46, 549-556.

FRUEHAN R. J. (1970) The thermodynamic properties of liquid FeSi Alloys. Metal. Trans. 1, 865-870.

Goldstein J. I. Newbury D. E., EChlin P., Joy D. C., Fiori C.. and LIFSHIN E. (1981) Scanning Electron Micruscopy and X-Rav Microanalysis. Plenum Press.

GoOley R. and Moore C. B. (1976) Native metal in diogenite meteorites. Amer. Mineral. 61, 373-378.

GREENBERG R. and CHAPMAN C. R. (1984) Asteroids and meteorites: Origin of stony-iron meteorites at mantle-core boundaries. Icans $57,267-279$.

HEwINS R. H. (1979) The composition and origin of metal in howardites. Geochim. Cusmochim. Acta 43, 1663-1674.

HewiNS R. H. and NEwSOM H. E. (1988) Igneous activity in the early solar system. In Meteorites and the Early Solar System (eds. J. F. KERRIDGE and M, S. SHAPLEY), pp. 73-101. University of Arizona Press.

HEWINS R. H. and ULMER G. C. (1984) Intrinsic oxygen fugacities 
of diogenites and mesosiderite clasts. Geochim. Cosmochim. Acta 48, $1555-1560$

Holmes R. D. and ARCulus R. J. (1983) Metal-silicate redox reactions: Implications for core-mantle equilibrium and the oxidation state of the upper mantle. LPI Tech. Rept. 83-01, 77-80.

Holmes R. D., O'NeILl H. ST. C., and ARCulus R. J. (1986) Standard Gibbs free energy of formation for $\mathrm{Cu}_{2} \mathrm{O}, \mathrm{NiO}, \mathrm{CoO}$ and $\mathrm{Fe}_{x} \mathrm{O}$ : High resolution electrochemical measurements using zirconia solid electrolytes from 900 to 1400 K. Geochim. Cosmochim. Acta 50, 2439-2452.

Holmes R. D., KERSTING A. B., and ARCulus R. J. (1989) Standard molar Gibbs free energy of formation for $\mathrm{Cu}_{2} \mathrm{O}$ : High resolution electrochemical measurements from 900 to $1300 \mathrm{~K}$. J. Chem. Therm. 21, 351-61.

JONFS J. H. (1984) The composition of the mantle of the eucrite parent body and the origin of eucrites. Geochim. Cosmochim. Acta 48, 641-648.

JoNeS J. H. and DRAKE M. J. (1986) Geochemical constraints on core formation in the Earth. Nature 322, 221-228.

Kersting A. B., ARculus R. J., Delano J. W., and Loureiro D. (1989) Electrochemical mcasurements bcaring on the oxidation state of the Skaergaard Layered Intrusion. Contrib. Mineral. Petrol. 102, 376-388.

KUBASCHEWSKI O. and AlCOCK C. B. (1979) Metallurgical Thermochemistry, 5th edn. Pergamon Press.

LONGHI J. and PAN V. (1988) Phase equilibrium constraints on the Howardite-Eucrite-Diogenite Association. Proc. I8th Lunar Planet. Sci. Conf., 459-470.

Loureiro D., Delano J. W., Leblanc M., Dautria J. M., GuRney J. J., and NIXON P. H. (1990) Electrochemical determinations of the oxygen fugacity in equilibrium with mantle-derived ilmenite megacrysts at 1 bar. (in prep.).

LOVERING J. F. (1957) Pressures and temperatures within a typical parent body. Geochim. Cosmochim. Acta 12, 253-261.

Malvin D. J., Wasson J. T., Clayton R. N., MAYEDa T. K., and DA Silva CuRvello W. (1985) Bocaiuva-a silicate inclusion bearing iron meteorite related to the Eagle Station pallasites. Meteoritics 20, 259-273.

Mason B. (1963) The pallasites. Amer. Mus. Novit. 2163, 1-19.

MATtioli G. H. and WoOD B. J. (1988) Magnetite activities across the $\mathrm{MgAl}_{2} \mathrm{O}_{4}-\mathrm{Fe}_{3} \mathrm{O}_{4}$ join, with application to thermobarometric estimates of upper mantle oxygen fugacity. Contrib. Mineral. Petrol. 98, 148-162.

Morgan J. W., Higuchi H., Takahashi H., and IIeRtogen J. (1978) A "chondritic" eucrite parent body: Inference from trace elements. Geochim. Cosmochim. Acta 42, 27-38.

NEWSOM H. E. (1985) Molybdenum in eucrites: evidence for a metal core in the eucrite parent body. Proc. 15th Lunar Planet. Sci. Conf.; J. Geophys. Res. 90, C613-C617.

Newsom H. E. and DRAKE M. J. (1982) The metal content of the Eucrite parent body: Constraints from the partitioning behavior of tungsten. Geochim. Cosmochim. Acta 46, 2483-2489.

NewSOM H. E. and DRAKE M. J. (1983) Experimental investigation of the partitioning of phosphorus between metal and silicate phases: Implications for the Earth, Moon and Eucrite Parent Body. Geochim. Cosmochim. Acta 47, 93-100.

Nininger H. H. (1932) The Springwater meteorite. Amer. Mineral. $17,396-400$.

OHTANI E. (1983) Formation of olivine textures in pallasites and thermal history of pallasites in their parent body. Phys. Earth Planet. Int. 32, 182-192.
OLSEN E. and FREDRIKSSON K. (1966) Phosphates in iron and pallasite meteorites. Geochim. Cosmochim. Acta 30, 459-470.

OLSEN E. and FuCHS L. H. (1967) The state of oxidation of some iron metcoritcs. Icarus 6, 242-253.

O'NEILL H. ST. C. (1987) Quartz-fayalite-iron and quartz-fayalitemagnetite equilibria and the free energy of formation of fayalite $\left(\mathrm{Fe}_{2} \mathrm{SiO}_{4}\right)$ and magnelite $\left(\mathrm{Fe}_{3} \mathrm{O}_{4}\right)$. Amer. Mineral. 72, 67-75.

Palme H., WlotzKa F., SpetTel B., Dreibus G., and Weber H. (1988) Camel Donga: a eucrite with high metal content. Meteoritics $23,49-58$.

RINGWOOD A. E. (1959) On the chemical evolution and densities of the planets. Geochim. Cosmochim. Acta 15, 257-283.

RINGWOOD A. E. (1961) Chemical and genetic relationships among meteorites. Geochim. Cosmochim. Acta 24, 159-197.

Robie R. A., Hemingway B. S., and FisHer J. R. (1978) Thermodynamic properties of minerals and related substances at 298.15 $\mathrm{K}$ and 1 Bar pressure and at high temperatures. US Geol. Surv. Bull. 1452.

ROBINSON G. R., JR., HAAS J. L., JR., SCHAFER C. M., and HASElton H. T., JR. (1983) Thermodynamic and thermophysical properties of selected phases in the $\mathrm{MgO}-\mathrm{SiO}_{2}-\mathrm{H}_{2} \mathrm{O}-\mathrm{CO}_{2}, \mathrm{CaO}-\mathrm{Al}_{2} \mathrm{O}_{3}-\mathrm{SiO}_{2-}$ $\mathrm{H}_{2} \mathrm{O}-\mathrm{CO}_{2}$, and $\mathrm{FeO}-\mathrm{Fe}_{2} \mathrm{O}_{3}-\mathrm{SiO}_{2}$ chemical systems with special emphasis on the properties of basalts and their mineral components. US Geol. Surv. Open-File Rept. 83-79.

SACK R. O. and GHIORSO M. S. (1989) Importance of considerations of mixing properties in establishing an internally consistent thermodynamic database: thermochemistry of minerals in the system $\mathrm{Mg}_{2} \mathrm{SiO}_{4}-\mathrm{Fe}_{2} \mathrm{SiO}_{4}-\mathrm{SiO}_{2}$. Contrib. Mineral. Petrol. 102, 41-68.

SAKAO H. and ElLIOT J. F. (1975) Thermodynamics of dilute bcc Fe-Si alloys. Metal. Trans. 6A, 1849-1851.

SATO M. (1971) Electrochemical measurements and control of oxygen fugacity and other gaseous fugacities with solid electrolyte systems. In Research Techniques for High Pressure and High Temperature (ed. G. C. ULMER), pp. 43-99. Springer-Verlag.

SATO M. (1978) A possible role of carbon in characterizing the oxidation state of a planetary interior and originating a metallic core. Lunar Planet. Sci. IX, 990-992.

SCOTT E. R. D. (1977a) Pallasites-metal composition, classification and relationships with iron meteorites. Geochim. Cosmochim. Acta 41, 349-360.

ScoTT E. R. D. (1977b) Formation of olivine-metal textures in pallasite meteorites. Geochim. Cosmochim. Acta 41, 693-710.

ShaRP Z. D., ESSENE E. J., ANOVITZ A. M., METZ G. W., WESTRUM E. F., JR., Hemingway B. S., and VALLEY J. W. (1986) The heat capacity of a natural monticellite and phase equilibria in the system $\mathrm{CaO}-\mathrm{MgO}-\mathrm{SiO}_{2}-\mathrm{CO}_{2}$. Geochim. Cosmochim. Acta 50, 1475-1484.

STOLPER E. (1977) Experimental petrology of eucritic meteorites. Geochim. Cosmochim. Acta 41, 587-611.

TAYLOR G. J. (1989) Metal segregation in asteroids. Lunar Planet. Sci. $X X, 1109-1110$.

TAYLOR H. P., JR., DUKe M. B., SIlver L. T., and EPSTein S. (1965) Oxygen isotope studies of minerals in stony meteorites. Geochim. Cosmochim. Acta 29, 489-512.

WAI C. M. and WASSON J. T. (1969) Silicon concentrations in the metal of iron meteorites. Geochim. Cosmochim. Acta 33, 14651471.

WARREN P. H. (1985) Origin of howardites, diogenites and eucrites: A mass balance constraint. Geochim. Cosmochim. Acta 49, 577586 .

WARREN P. H. and JeRDE E. A. (1987) Composition and origin of Nuevo Laredo Trend eucrites. Geochim. Cosmochim. Acta 51, 713-726. 